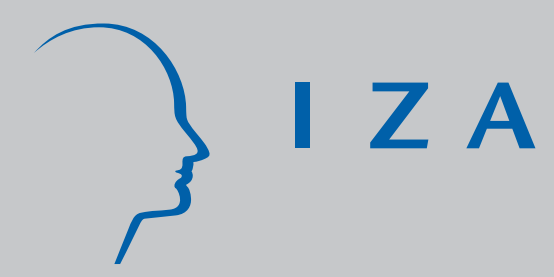

IZA DP No. 1398

How Different Are Immigrants?

A Cross-Country and Cross-Survey Analysis of Educational Achievement

Sylke Viola Schnepf

November 2004 


\title{
How Different Are Immigrants? A Cross-Country and Cross-Survey Analysis of Educational Achievement
}

\author{
Sylke Viola Schnepf \\ $S^{3} R I$, University of Southampton, \\ University of Hamburg and IZA Bonn
}

Discussion Paper No. 1398

November 2004

\author{
IZA \\ P.O. Box 7240 \\ 53072 Bonn \\ Germany \\ Phone: +49-228-3894-0 \\ Fax: +49-228-3894-180 \\ Email: iza@iza.org
}

\begin{abstract}
Any opinions expressed here are those of the author(s) and not those of the institute. Research disseminated by IZA may include views on policy, but the institute itself takes no institutional policy positions.

The Institute for the Study of Labor (IZA) in Bonn is a local and virtual international research center and a place of communication between science, politics and business. IZA is an independent nonprofit company supported by Deutsche Post World Net. The center is associated with the University of Bonn and offers a stimulating research environment through its research networks, research support, and visitors and doctoral programs. IZA engages in (i) original and internationally competitive research in all fields of labor economics, (ii) development of policy concepts, and (iii) dissemination of research results and concepts to the interested public.
\end{abstract}

IZA Discussion Papers often represent preliminary work and are circulated to encourage discussion. Citation of such a paper should account for its provisional character. A revised version may be available directly from the author. 
IZA Discussion Paper No. 1398

November 2004

\section{ABSTRACT}

\section{How Different Are Immigrants? A Cross-Country and Cross-Survey Analysis of Educational Achievement}

This paper examines differences in educational achievement between immigrants and natives in ten countries with a high population of immigrant pupils: Australia, Canada, France, Germany, the Netherlands, New Zealand, Sweden, Switzerland, the UK and the USA. The first step of the analysis shows how far countries differ regarding immigrants' educational disadvantage. In a second step, the paper compares immigrants' characteristics across countries focusing predominantly on socioeconomic status, language proficiency, immigrants' time spent in the host country and patterns of school segregation. Using a regression framework the last step of the analysis investigates how far these determinants of educational achievement can explain immigrants' educational disadvantage in the countries examined. The paper evaluates whether results found are robust across different sources of achievement data: the Trends in International Maths and Science Study (TIMSS), the Programme of International Student Assessment (PISA) and the Programme of International Reading Literacy Study (PIRLS).

JEL Classification: $\quad$ I21, J15, 015

Keywords: $\quad$ education, immigration, PISA, TIMSS, PIRLS

Sylke Viola Schnepf

Southampton Statistical Sciences Research Institute

University of Southampton

Southampton SO17 1BJ

United Kingdom

Email:svs@soton.ac.uk 


\section{Introduction}

In many OECD countries migration plays an important and growing role in contributing to the population growth. The education of immigrants is a determining factor for their integration into the labour market and the society. The first aim of this paper is to analyse how immigrants differ from natives regarding educational outcomes and its determinants. We focus on ten immigration countries where the share of the foreign born in the total population is similar or greater than 10 percent ${ }^{1}$ : Australia, Canada, France, Germany, the Netherlands, New Zealand, Sweden, Switzerland, the UK and the USA.

Literature examining educational disadvantages of immigrants focus generally on data on educational attainment that captures progression up national educational systems (e.g. Ours and Veenman 2001, Riphahn 2002). The aim of this paper is to examine educational achievement that refers to educational outcomes like ability or 'functional literacy' (the ability to function in modern society). Educational achievement can be compared more easily across countries than educational attainment that partly reflects countries' institutional differences in how education is organised. In addition, a specific degree used as a measure of educational attainment might mirror different ability for immigrants and natives even in the same country. In general, immigrants have a lower informational access on their host countries educational system. Hence, their chances to reach a specific educational attainment are not only dependent on their general ability but also on their integration into the host country. The focus on educational achievement overcomes these problems and is only seldom applied in the literature ${ }^{2}$.

For examining educational achievement we can make use of recent international surveys of learning achievement of children in compulsory school. These surveys focus on what pupils actually know or can do. But which achievement survey to use? Each survey aims to assess something different (e.g. maths or reading achievement) or to assess knowledge in a different way (e.g. in relation to an

\footnotetext{
${ }^{1}$ See OECD 2003 and Table A1 in the appendix.

${ }^{2}$ One very recent exemption is Entorf and Minoiu (2004). This paper uses exclusively PISA data for comparing achievement differences between immigrants and natives in 8 high and one low immigration country. Besides the approach of testing the robustness of survey results by using PISA, TIMSS and PIRLS data our paper emphasise the transparency of determinants of educational achievement used and explains the extent of immigrants disadvantage in terms of something readily
} 
'international' curriculum versus the ability to apply knowledge in everyday settings) and uses different methods for assessment (more open-ended or multiple-choice questions). Due to immigrants' limited language skills and different cultural background we might expect them to fare better in the subject maths than reading, in a more "curriculum based" approach measure of ability and with non-wordy multiplechoice questions. Hence, the variations between surveys are very likely to impact upon educational achievement results for immigrants. Our second aim in this paper is to pull together the evidence from three different surveys to see if a robust picture exists on immigrants' educational disadvantage in the ten high immigration countries.

There are several factors that impact upon differences in educational achievement between immigrants and natives. These factors motivate the research interest of this paper but also show its limitations.

First, educational achievement per se is determined greatly by pupils' socioeconomic background. For this reason, differences between immigrants and natives regarding their family background can be a determining factor for achievement differences between both groups of children. Hence, a main research interest of this paper regards the question in how far the different composition of immigrants and natives is related to their differences in educational achievement. Nevertheless, SES is partly unobservable, especially if we focus on parental education that is measured by educational attainment. An immigrant's mother who has completed upper secondary education in Mexico and a native's mother who holds an upper secondary degree achieved in the USA have probably a quite different quality of education. Hence, the level of parental education can be equal not meaning that also the quality of parental education is similar. We use also another more easily comparable measure of SES across countries - books at home -, nevertheless, up to a certain degree we cannot capture the "real" amount of SES differences between immigrant and native pupils.

Second, educational achievement differences can also derive from immigrants' problems of integration into the host country. On one hand, the ability of the immigrant pupil to communicate in the language of the host country is a crucial factor for educational achievement. Hence, we estimate the impact of a foreign language spoken at home on educational achievement. In addition, by focusing on different

understood. In addition, we focus on immigrants' educational achievement dispersion and examine also the impact on the school level by focusing on school segregation. 
subjects it will also be examined whether the immigrants' achievement gap is smaller for more technical subjects requiring less language skills like maths.

On the other hand, the problem of integration into the host society is also related to a lack of familiarity or information about the national education system.

However, the difficulty of integrating into a host society is a function of the time pupils are living in the host country. We will therefore focus not only on immigrants defined as pupils whose both parents were born abroad but also give some achievement results on two different kinds of immigrants: a) non-native immigrant pupils who were born abroad and b) first-generation immigrant pupils who were born in the host countries.

Nevertheless, integrating into the host society might also be complicated by residential and school segregation. A high clustering of ethnicities in neighbourhoods is likely to decelerate the integration process since there is less exchange with natives than in a 'mixed' environment. In addition, a high school segregation (that is often related to high residential segregation) might have some impact on immigrants' educational achievement. Pupils are likely to be influenced by their peers' school ambitions and these are likely to be different in highly segregated schools. This provides the motivation for this paper to estimate additionally the impact of school segregation on educational achievement gaps between immigrants and natives.

Third, even if socio-economic background between immigrants and natives were equal and immigrants were integrated successfully into the society, the process of selection impacting upon the characteristics of migrants living in a host country might still mould achievement differences between natives and immigrants. On one hand, a selection through immigration control takes place. In traditional countries of immigration like Australia, New Zealand and Canada immigration policies try to attract highly skilled immigrants (Inglis 2002, Ray 2002, Bedford 2003). These immigrants are very likely to differ in their motivations and expectations from immigrants in the former 'guest worker' countries like Switzerland and Germany (Castles and Miller 2003). Partly, it is possible to take these selection effects into account by focusing on the before discussed issue of socio-economic background. However, besides SES also motivations and expectations of immigrants on their life in the host country are very much likely to impact upon their offsprings' educational achievement. Hence, the selection issue remains partly an unobservable that cannot be properly addressed by comparing educational achievement gaps between immigrants 
and natives. This is also true for the self-selection of immigrants. The self-selection of immigrants captures that fact, that immigrants might have very different characteristics depending on the host country they decide to live in and their country of origin. Turkish immigrants deciding to live in Canada might be much different from Turkish immigrants living in Germany. Asian immigrants differ greatly from Mexican immigrants in the US (Schmid 2001, Glick and White 2003). A focus on educational dispersion between immigrants can give an impression how different immigrants' educational achievement is in the high immigration countries. Hence, we will compare the achievement distributions of immigrants with those of natives. However, the focus on immigrants' dispersion can only indicate the very different nature of immigrants in one country but cannot capture the effect of selection that is likely to determine achievement differences between immigrants and natives differently in diverse countries.

The paper is structured as follows. Section 2 introduces the three surveys we draw on: the Trends in International Maths and Science Study (TIMSS), the Programme of International Student Assessment (PISA) and the Programme of International Reading Literacy Study (PIRLS). Section 3 examines how different immigrants are regarding their educational achievement and compares educational dispersion between immigrants and natives across countries and surveys. Section 4 discusses the differences in socio-economic background between immigrants and natives and examines school segregation in the ten high immigration countries.

However, are countries differences in immigrants' educational disadvantage a mere function of immigrants' differences in socio-economic background compared to natives? Can school segregation explain the immigrants' achievement gap found in some countries? Section 5 uses a regression framework for examining these questions and compares regression results across surveys and countries. Section 6 concludes.

\section{Data}

Table 1 lists the educational achievement surveys ${ }^{3}$ and their coverage of ten countries selected for this analysis due to their high share of immigrant pupils and their participation in at least two of the surveys. All three data sources relate to children in compulsory schooling and are recent pertaining to 1995, 1999, 2000 and 2001. While

\footnotetext{
${ }^{3}$ Details on the surveys can be found in their reports: Mullis et al (2000), Mullis et al (2003), OECD and Statistics Canada (2000) and OECD (2001).
} 
PIRLS focused on primary school children aged 9-10 years ${ }^{4}$, TIMSS and PISA covered children in secondary school. PISA data focused on pupils who are 15 years old, TIMSS ${ }^{5}$ covered $7^{\text {th }}$ and $8^{\text {th }}$ graders. The surveys' sample designs involve the selection of a sample of schools and then a single class (TIMSS and PIRLS) or a random sample (PISA) of pupils within each school.

The three surveys differ considerably so that the choice of the survey for examining natives' and immigrants' achievement might impact upon the results. Different surveys assessed different types of achievement, covered different subjects and collected information differently. PISA assessed ability in reading, science and maths with the aim to measure broad skills, trying to look at how students would be able to use what they have learned in real-life situations. PIRLS measured primary school children's reading and understanding capability of written texts. In contrast to PISA and PIRLS, TIMSS focused on assessing a mastery of internationally agreed curricula in the subjects maths and science.

PISA assessed achievement predominantly by using open-ended questions. In contrary, about two-thirds of the TIMSS questions were multiple choice in 1999. Since on average immigrants have lower language skills than their native counterparts, achievement gaps are likely to be lower between native and immigrant pupils with the ability measure of TIMSS that uses multiple choice questions on technical curriculum based subjects like maths and science.

In addition, surveys differ regarding their application of aggregation methods for transferring results into the final analysed achievement measure. Survey organisers do not report the sensitivity of results to the choice of model but Brown and Micklewright (2003) show with TIMSS data that this is not a trivial issue. Other differences can be cited, including response rates. Even the basic premise that culturally-neutral questions can be successfully designed and translated into different languages can be debated, with the problems in this area probably

\footnotetext{
${ }^{4}$ PIRLS assessed children in the upper of the two grades with the most 9-year-olds at the time of testing. This corresponds to the fourth grade and an average age of about 10 years for most of the countries.

${ }^{5}$ TIMSS 1995 covered $3^{\text {rd }}$ and $4^{\text {th }}$ grades, $7^{\text {th }}$ and $8^{\text {th }}$ grades and the last grade of secondary schooling. TIMSS 1999 assessed children in the $8^{\text {th }}$ grade only. We focus on $8^{\text {th }}$ grade data for 1995 for all countries except for USA where most recent data is available for all variables used in the regression analysis. (England, New Zealand, Canada, Australia and Netherlands did participate in 1999 but did not administer all data on pupils family background in this year. In order to be consistent with data used the analysis refers always to 1995 data for these countries.) When using 1995 data we used 'rescaled' data - scores derived from a psychometric model of the same form as that used for the 1999 data.
} 
varying from survey to survey. ${ }^{6}$ In short, there seems ample reason for comparing results across the different surveys rather than relying on a single source.

Table 1: Educational surveys and immigration countries coverage

\begin{tabular}{lccc}
\hline \hline \multicolumn{1}{c}{ Testing of } & TIMSS 1999/ 1995 & PISA 2000 & PIRLS 2001 \\
\hline \multicolumn{1}{c}{ Subjects covered } & $8^{\text {th }}$ graders & 15 year-olds & $4^{\text {th }}$ graders \\
\hline Australia & Mathematics, Science & $\begin{array}{c}\text { Reading Mathematics } \\
\text { Science }\end{array}$ & Reading \\
Canada & $\mathrm{X}$ & $\mathrm{X}$ & \\
France & $\mathrm{X}$ & $\mathrm{X}$ & $\mathrm{X}$ \\
Germany & & $\mathrm{X}$ & $\mathrm{X}$ \\
Netherlands & $\mathrm{X}$ & $\mathrm{X}$ & $\mathrm{X}$ \\
New Zealand & $\mathrm{X}$ & $\underline{X}$ & $\mathrm{X}$ \\
Sweden & $\mathrm{X}$ & $\mathrm{X}$ & $\mathrm{X}$ \\
Switzerland & $\mathrm{X}$ & $\mathrm{X}$ & $\mathrm{X}$ \\
UK & $\mathrm{X}$ & $\mathrm{X}$ & $\mathrm{X}$ \\
USA & $\mathrm{X}$ & $\mathrm{X}$ & $\mathrm{X}$ \\
\hline \hline
\end{tabular}

Note: TIMSS and PIRLS are organised by the International Study Center, Boston College, USA. PISA is organised by OECD. France is covered by TIMSS in 1995, but the variable used for the calculation of pupils' immigration status was not administered. Data on Germany, Sweden and Switzerland refer to 1995 for TIMSS; in the regression analysis only data of the USA refer to 1999 (for details see appendix). Data for UK in TIMSS and PIRLS refer to England and Scotland only. Data on Netherlands for PISA might be biased due to very low response rate. Nevertheless, we decided to use this data, since it is possible to compare PISA results with results of the other two surveys.

Table 1 shows that PISA covered all ten countries with a high immigration background, while Australia and Switzerland did not participate in PIRLS. TIMSS covered all ten countries, but the variable used for the calculation of pupils' immigration status was not administered in France.

In all three surveys information were collected in the same format regarding two immigration variables: First, whether pupils, their mothers and fathers were born in the test country or abroad and second, how often the language of the test country is spoken at home. For the purpose of this paper immigrants are defined as pupils whose both parents were born abroad. First generation immigrants were born in the test country while non-native immigrants where born abroad. Children who are not immigrants, hence who have at least one parent born in the test country, are referred to as natives. Table A1 in the appendix presents the share of the immigrants in the surveys' sample and the foreign born population expressed as share of the countries' population based on OECD data. In general, estimates of percentages of pupils with

\footnotetext{
${ }^{6}$ Overall country response rates in TIMSS and PISA averaged 88 percent (after replacement of nonresponding schools with substitutes) and 85 percent respectively. Response in PIRLS averaged 92 percent (unweighted) and in IALS 62 percent. Variation across countries can be marked. Blum et al (2001) consider France's experience in IALS (a survey on adults literacy) and among other things make critical comparison of the French language questionnaire used in France and that used in Switzerland. (France originally participated and then later withdrew.)
} 
immigration background are relatively similar between surveys. An exception is the USA with a share of immigrant pupils of 10 percent for TIMSS and a very high percentage of 20 for PIRLS.

\section{Educational achievement gaps between immigrants and natives}

We start the discussion of achievement gaps between immigrants and natives by focusing on just one subject and survey, maths achievement in TIMSS. Figure 1 presents the percentage of natives (x-axis) and immigrants (y-axis) who do not reach the international TIMSS maths median. These children are viewed as 'unable to apply basic mathematic knowledge in straightforward situations' by the organisers. (Obviously these classifications are open to debate.) For each country two values are given on the y-axis, one value for first-generation immigrants (born in the test country, indicated by the square) and one value for non-native immigrants (born abroad, indicated by diamond). Immigrants in Canada, Australia, the UK and nonnative immigrants in New Zealand are situated around the 45 degree line showing that the percentage of immigrants and natives achieving below TIMSS math international median are similar in these countries. For the other countries a higher percentage of immigrants than natives are unable to solve basic maths tasks. In Switzerland, Sweden, Germany and the USA the share of non-native immigrants lacking basic maths skills is significantly higher than that of first-generation immigrants, indicating that pupils grown up in the host country are achieving better than newly arrived immigrant pupils. As argued before, a higher integration into the host country due to longer time spent in that country is likely to impact positively on achievement score. However, in Netherlands and New Zealand we find the reverse effect, with a lower share of newly arrived immigrants than those born in the country who cannot solve basic mathematic tasks (PISA maths achievement scores show the same counterintuitive result only for New Zealand). This result for Netherlands and New Zealand might be explained by the much higher level of parental education for non-native than for first-generation immigrants ${ }^{7}$.

\footnotetext{
${ }^{7}$ Given TIMSS data, 46 percent of the parents of first-generation immigrants in New Zealand have completed secondary education compared to 65 percent of parents of non-natives. The trend is smaller in the Netherlands with 21 percent of first-generation and 29 percent of non-native immigrants' parents who completed secondary schooling. Similar results for Netherlands are found by van Ours and Veenman (2000).However, also in Australia and Germany the parental education of non-natives is on average higher than that of first-generation immigrants.
} 
Figure 1: Percentage of natives and immigrants (first-generation immigrants and non-native immigrants) achieving below the international TIMSS median

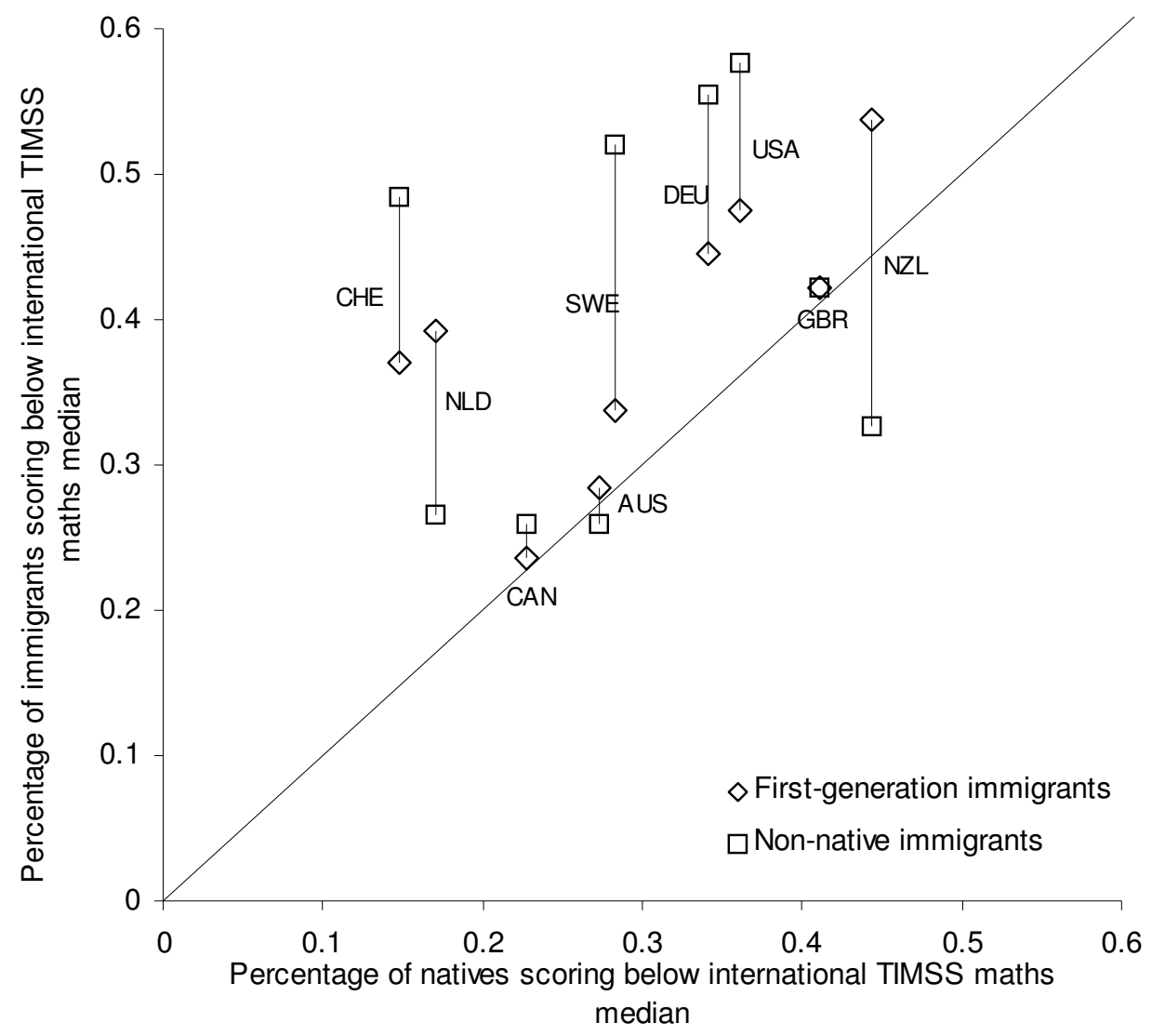

Note: Immigrant pupils are pupils whose both parents were born in a foreign country. Non-native immigrant pupils were born abroad and first-generation immigrants were born in the test country. Native pupils refer to all other children.

However, the most surprising result of Figure 1 is the great difference in percentages of natives and immigrants not able to solve basic maths tasks in some of the countries examined. In Germany and Sweden more than 20 percent and in Switzerland more than 30 percent of non-native immigrants than of natives fall below the international median of TIMSS maths achievement. Expressed differently, one and a half times more non-native immigrants than natives in the US, Germany and Netherlands, about two times more in Sweden and three times more in Switzerland are unable to solve basic maths tasks. On the other hands, the percentage of low achieving immigrants is very similar to that of natives in the English-speaking countries Canada, Australia and the UK.

In PISA, children who score beneath a critical benchmark level of competence (the reading literacy level 2) are viewed as 'unable to solve basic reading tasks such as 
locating straightforward information'. Applying this survey organisers' benchmark to pupils with different migration background (without differentiation between nonnatives and first-generation immigrants) shows that the group of immigrants unable to solve basic reading tasks is about 10 percent higher than the groups of natives in the UK, France and USA, 20 percent higher in the Netherlands, Switzerland and Sweden and even 30 percent higher in Germany. In line with TIMSS results, the percentage of low ability pupils is similar for natives and immigrants in Canada, Australia and New Zealand.

Up to now we compared percentages of immigrant and native pupils falling below an absolute educational benchmark. The advantage of this approach is that it is possible to attribute a meaning in form of a statement about ability to students achieving below the benchmark. The disadvantage is that pupils are divided solely in two groups: those above and those below the international benchmark. ${ }^{8}$ A more common way for reporting educational achievement results is to report the countries' average survey scores. These scores lack a natural metric and are therefore difficult to interpret. In general, countries covered in the surveys ${ }^{9}$ have a mean score set to 500 and a standard deviation of 100 .

Figure 2 presents average achievement scores for all immigrants (x-axis) and natives (y-axis) for PISA reading. With the exception of Ireland and Hungary all countries are situated above the 45 degree line indicating that natives fare better in reading achievement than immigrants.

The general picture reveals that the selected ten high immigration countries are evenly distributed among other OECD countries and hence do not differ greatly from them regarding achievement gaps between pupils with different immigration background. The small correlation coefficient between achievement of natives and the achievement gaps between immigrants and natives (the difference between natives' and immigrants' mean achievement) of 0.18 for all OECD countries covered indicates that countries with high average educational achievement (e.g. Finland and

\footnotetext{
${ }^{8}$ Another disadvantage regarding the focus on absolute educational disadvantage regards the general country level of achievement. Differences between immigrants and natives in a country can be large but do not translate into great differences between shares of low ability immigrants and nativesin case the countries' mean achievement is very high.

${ }^{9}$ The problem for comparing different survey scores is that each survey covers a different set of countries. For example, the mean score of 500 applies only to OECD countries for PISA but to all countries covered by PIRLS (including e.g. Kuwait and Iran).
} 
Netherlands) are not necessarily successful in limiting immigrants' educational disadvantage.

Figure 2: PISA reading mean achievement scores for natives and immigrants

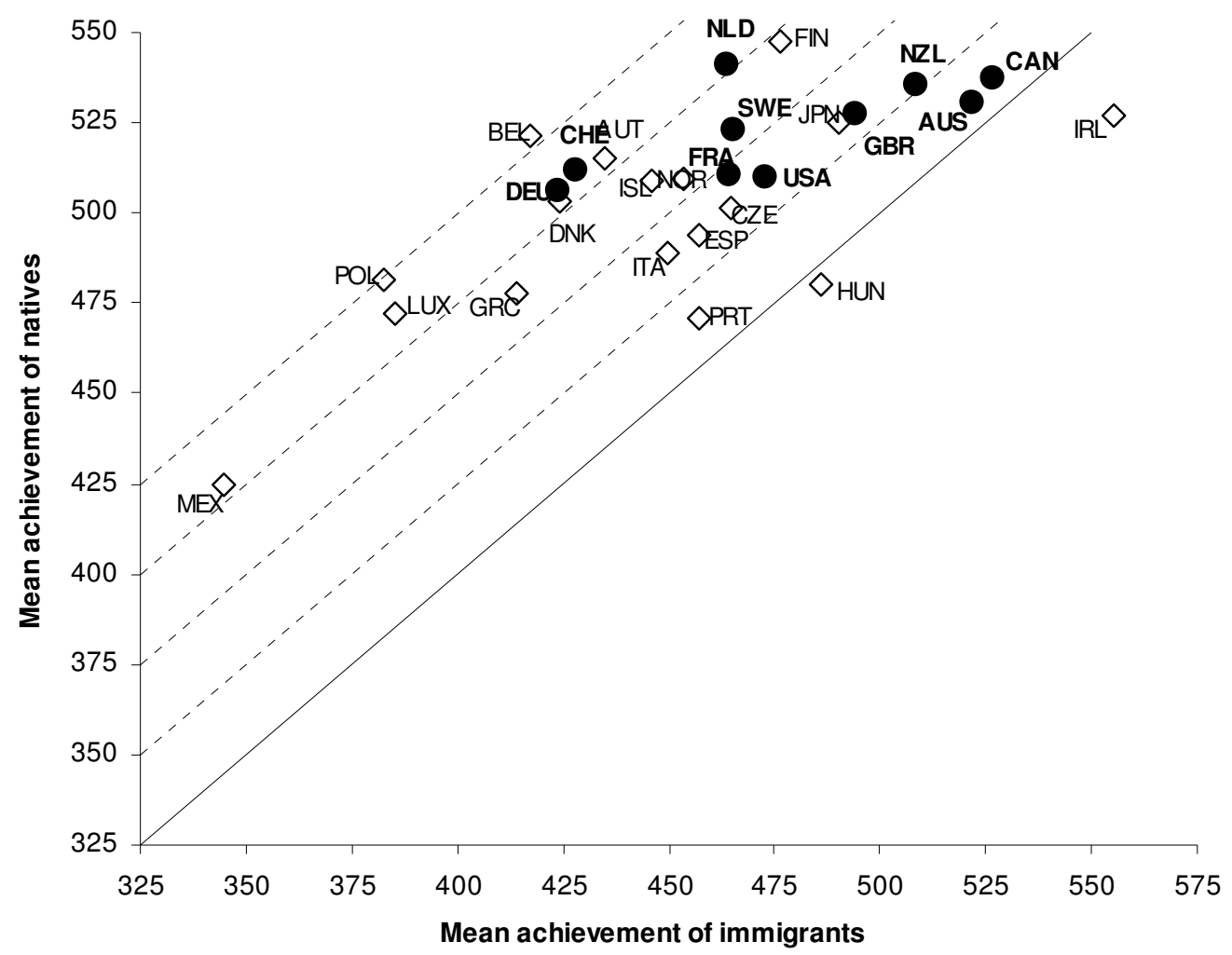

Note: Immigrant pupils are pupils whose both parents were born in a foreign country; native pupils refer to all other children.

Differences between the high immigration countries are large. There does not seem to be a big achievement gap between the two groups of pupils in Englishspeaking countries in general; especially in Australia and Canada immigrants are not greatly different from natives regarding their educational achievement. On the other hand, point differences are considerably high for pupils in Germany, Switzerland and the Netherlands where immigrants received an average achievement score 75 points below that of natives. As discussed before, for Germany this is similar to 30 percent more immigrants than natives who are not able to solve basic reading tasks. Sweden, France and the US are in a middle position given that immigrants show an about 40 to 60 point lower average achievement than natives.

Is this result on country differences in immigrants' educational achievement gap robust if we focus on other subjects and surveys? 
Table 2: Differences in average scores between native and immigrant pupils

\begin{tabular}{lcccccc} 
& \multicolumn{3}{c}{ PISA } & \multicolumn{3}{c}{ TIMSS } \\
& Read & Maths & science & maths & science & Read \\
Switzerland & $\mathbf{- 8 3 . 6}$ & $\mathbf{- 8 3 . 8}$ & $\mathbf{- 8 3 . 2}$ & $\mathbf{- 5 7 . 4}$ & $\mathbf{- 8 5 . 0}$ & \\
Germany & $\mathbf{- 8 2 . 3}$ & $\mathbf{- 8 0 . 0}$ & $\mathbf{- 9 1 . 3}$ & $\mathbf{- 3 9 . 8}$ & $\mathbf{- 7 8 . 8}$ & $\mathbf{- 5 1 . 4}$ \\
Netherlands & $\mathbf{- 7 7 . 5}$ & $\mathbf{- 8 9 . 7}$ & $\mathbf{- 9 9 . 9}$ & $\mathbf{- 3 2 . 0}$ & $\mathbf{- 4 9 . 2}$ & $\mathbf{- 4 2 . 4}$ \\
Sweden & $\mathbf{- 5 7 . 8}$ & $\mathbf{- 6 2 . 9}$ & $\mathbf{- 5 8 . 1}$ & $\mathbf{- 3 3 . 9}$ & $\mathbf{- 6 1 . 7}$ & $\mathbf{- 4 3 . 7}$ \\
France & $\mathbf{- 4 6 . 9}$ & $\mathbf{- 4 3 . 8}$ & $\mathbf{- 6 5 . 4}$ & & & $\mathbf{- 3 0 . 4}$ \\
USA & $\mathbf{- 3 7 . 7}$ & $\mathbf{- 3 8 . 4}$ & -38.8 & $\mathbf{- 3 0 . 7}$ & $\mathbf{- 5 2 . 2}$ & $\mathbf{- 3 1 . 0}$ \\
UK & $\mathbf{- 3 3 . 6}$ & $\mathbf{- 3 6 . 7}$ & $\mathbf{- 3 5 . 0}$ & -0.7 & -19.1 & $\mathbf{- 3 3 . 3}$ \\
New Zealand & $\mathbf{- 2 7 . 4}$ & -13.2 & $\mathbf{- 2 4 . 2}$ & -10.9 & $\mathbf{- 3 4 . 6}$ & -4.7 \\
Canada & $\mathbf{- 1 0 . 9}$ & $\mathbf{- 9 . 3}$ & $\mathbf{- 2 1 . 3}$ & $-\mathbf{1 4}$ & $\mathbf{- 3 5 . 0}$ & $\mathbf{- 1 7 . 8}$ \\
Australia & -9.2 & -3.9 & -10.2 & -3.0 & -17.0 &
\end{tabular}

Note: Countries are ordered by mean achievement differences in PISA reading, bold figures mean that achievement differences between natives and migrants are significant at the $1 \%$ level. Immigrant pupils are pupils whose both parents were born in a foreign country; native pupils refer to all other children. For TIMSS data refer to 1999 for the USA and to 1995 for all other countries.

Table 2 presents the point differences in average achievement scores between immigrants and natives for the three surveys and subjects. Countries are ordered by achievement gaps in PISA reading. Negative figures printed bold indicate that immigrants achievement is significantly worse ( 1 percent level) than that of natives.

TIMSS data can give us a reasonable tool at hand for interpreting differences in mean achievement scores between immigrants and natives. TIMSS tested $7^{\text {th }}$ and $8^{\text {th }}$ graders in 1995 . On average ${ }^{11}, 8^{\text {th }}$ graders show an about 30 point higher achievement in TIMSS maths and fare 40 points better in TIMSS science than $7^{\text {th }}$ graders. Expressing the native-immigrant achievement gap in years of grade progression shows how many years of schooling immigrants lack compared to natives.

In almost all countries and surveys immigrants achieve significantly lower test scores than natives. In addition, survey and subject results show a relatively consistent ranking of countries on achievement differences between immigrants and natives. Switzerland, Germany and Netherlands appear to have greatest differences between both groups of pupils throughout most of the surveys' measures. In these three countries TIMSS results show that pupils whose parents were born abroad lack about

\footnotetext{
${ }^{10}$ With more recent TIMSS data for 1999 immigrants educational disadvantage is higher for the Netherlands ( -37 points for maths and -65 points for science) and smaller for Canada ( -3 points for maths and -26 points for science) and New Zealand ( +6 points for maths and -21 for science). These results comply more with PISA results.

${ }^{11}$ This average refers to the 10 countries analysed here. Due to lack of space we limit the discussion on average country differences between mean upper and mean lower grade achievement. However, there are notable country differences in grade progression. E.g. in Netherlands and Germany $8^{\text {th }}$ graders perform only about 20 points better than $7^{\text {th }}$ graders, while pupils in the upper grade in Sweden perform about 37 points better than their lower grade counterparts.
} 
one year of schooling compared to natives in maths and almost two in science. Immigrants in Sweden fare better regarding their educational disadvantage in PISA than these three countries, but similarly bad in TIMSS and PIRLS. The second country group contains France, the USA and the UK, with a still moderate achievement difference between immigrants and natives. The last group of countries, Canada, Australia and New Zealand, consists of an immigrant population that faces only low or no significant educational disadvantages compared to the native population.

Also the correlation coefficients between all surveys given in Table A2 in the appendix indicate the high agreement between surveys on immigrants disadvantage in countries. The lowest correlation coefficient between surveys is for achievement gaps in PIRLS reading and TIMSS science with $0.67^{12}$.

We might expect that immigrants' educational disadvantage is smaller in subjects where language skills are generally of a lower importance like in maths. ${ }^{13}$ However, achievement in maths in PISA is measured by applying the 'life-skill' approach related to open-ended questions on wordy descriptions of 'real life' situations. Hence, it is not necessarily surprising, that immigrants do not fare better in maths in PISA. This result stands in contrast to TIMSS: for all countries immigrants' educational achievement gap is significantly lower in TIMSS maths than in TIMSS science. Hence, there seems to be the tendency that immigrants' educational disadvantage is smaller in technical subjects as long as achievement is assessed in a more curriculum based approach by using predominantly multiple-choice questions (like done in TIMSS).

Given that, we might also expect that in subjects that require mainly language skills newly arrived non-native immigrants show lower educational achievement than first-generation immigrants. Table 3 splits average achievement differences between natives and immigrants given in Table 2 for PISA and PIRLS reading into average achievement differences between natives and non-native immigrants and between natives and first-generation immigrants.

\footnotetext{
${ }^{12}$ Once TIMSS results for 1999 are correlated (see footnote before) the lowest correlation coefficient between surveys is 0.8 (PISA science with PIRLS reading) indicating the even greater agreement between surveys once the most recent data are used.
} 
Table 3: Differences in average scores between native and immigrant pupils (first-generation and non-native immigrants) for PISA and PIRLS reading

\begin{tabular}{lcc|cc}
\hline & \multicolumn{2}{c|}{ PISA reading } & \multicolumn{2}{c}{ PIRLS reading } \\
& $\begin{array}{c}\text { First } \\
\text { generation } \\
\text { immigrants }\end{array}$ & $\begin{array}{c}\text { Non-native } \\
\text { immigrants }\end{array}$ & $\begin{array}{c}\text { First } \\
\text { generation } \\
\text { immigrants }\end{array}$ & $\begin{array}{c}\text { Non-native } \\
\text { immigrants }\end{array}$ \\
\hline Switzerland & $\mathbf{- 5 2}$ & $\mathbf{- 1 0 9}$ & & \\
Germany & $\mathbf{- 7 3}$ & $\mathbf{- 8 7}$ & $\mathbf{- 3 7}$ & $\mathbf{- 6 2}$ \\
Netherlands & $\mathbf{- 7 2}$ & $\mathbf{- 8 7}$ & $\mathbf{- 5 0}$ & $\mathbf{- 3 4}$ \\
France & $\mathbf{- 4 0}$ & $\mathbf{- 7 6}$ & $\mathbf{- 2 7}$ & $\mathbf{- 3 7}$ \\
Sweden & $\mathbf{- 3 9}$ & $\mathbf{- 7 2}$ & $\mathbf{- 3 3}$ & $\mathbf{- 5 5}$ \\
UK & $\mathbf{- 2 0}$ & $\mathbf{- 7 0}$ & 1 & $\mathbf{- 5 6}$ \\
USA & $\mathbf{- 3 2}$ & $\mathbf{- 4 4}$ & -8 & $\mathbf{- 4 8}$ \\
New Zealand & $\mathbf{- 2 6}$ & $\mathbf{- 2 8}$ & -6 & -4 \\
Canada & 3 & $\mathbf{- 2 6}$ & 3 & $\mathbf{- 3 1}$ \\
Australia & -1 & $\mathbf{- 1 7}$ & & \\
\hline \hline
\end{tabular}

Note: $\overline{\text { Countries are ordered by average achievement differences between natives and non-native }}$ immigrants in PISA reading; bold figures mean that achievement differences between natives and migrants are significant at the $1 \%$ level.

Only for one country and survey (Netherlands in PIRLS) the average mean achievement difference between non-native immigrants and natives is smaller than that between first-generation immigrants and natives. In addition, the achievement gap is considerably higher for non-native immigrants than for first-generation immigrants for some countries. This is especially true for Switzerland, Sweden and the UK where non-natives' achievement gap compared to natives is twice as high as that of first-generation immigrants.

Until now the discussion of immigrants' educational disadvantage treated pupils with parents born abroad as a more or less homogenous group. However, there is some evidence, that immigrants are not almost worse performers as average calculations applied before imply for some countries. Immigrant pupils can differ greatly depending on their parents' country of origin, ethnicity and socio-economic background. Some literature show that Asian pupils outperform natives in the US (Glick and White 2003) and Chinese and Indian pupils are better achievers than their English counterparts (Demie 2001). Even though the survey data do not allow for this specification, it is possible to examine differences between immigrants by investigating the variation in their achievement. A focus on immigrants' achievement distribution compared to natives can also shed light on where achievement differences between natives and immigrants derive from in different countries. Are immigrants

\footnotetext{
${ }^{13}$ Given that survey organisers claim their assessment measure not to be culturally biased, we might assume that achievement differences between immigrants and natives do not derive from
} 
always worse performers than natives? Or is there only a greater share of badly performing immigrants than natives that leads to an on average lower performance of immigrants? In all ten countries for PISA reading and in seven countries (of nine) for TIMSS maths immigrants' dispersion is higher than that of natives (see Table A3 in the appendix giving the difference between the $95^{\text {th }}$ and $5^{\text {th }}$ percentile in achievement for immigrants and natives separately). This suggests that immigrants' achievement distribution is not similar to that of natives and not only shifted into the direction of lower achievement.

In order to compare the achievement distribution of immigrants and natives we estimate the achievement points for the $5^{\text {th }}, 10^{\text {th }}, 15^{\text {th }}, \ldots$ and $95^{\text {th }}$ percentile for both groups of children separately for the ten countries (achievement scores by percentile and migration background are reported in Table A4 in the appendix). Then we calculate the ratio of the achievement scores (immigrants' score divided by natives' score) for each percentile and country. The results are presented in Figure 3.

Throughout all countries and percentiles the ratio is smaller than 1 indicating that immigrants' achievement is in all percentiles worse than that of natives. In addition, for all countries immigrants' achievement disadvantage is always more pronounced at the bottom than at the top of the two distributions. However, countries differ regarding the intercept and the slope of the achievement ratio.

Not surprisingly, countries where immigrants' educational achievement is similar to that of natives (Australia, Canada and New Zealand) appear to have an achievement ratio closer to 1 across all percentiles than countries with greater average achievement gaps like Netherlands, Germany and Switzerland (see country ranking in Table 2). In Australia and Canada, immigrants at the bottom of the achievement distribution $\left(5^{\text {th }}\right.$ percentile) show an only about 5 percent lower reading achievement than natives in the same percentile. On the other hand, in Switzerland, Germany and Netherlands immigrants at the bottom of the distribution have achievement scores that are about 25 percent lower than that of their native counterparts situated in the $5^{\text {th }}$ percentile.

misunderstandings of cultural contents. 
Figure 3: Ratio of achievement scores of immigrants to natives by percentile for PISA reading

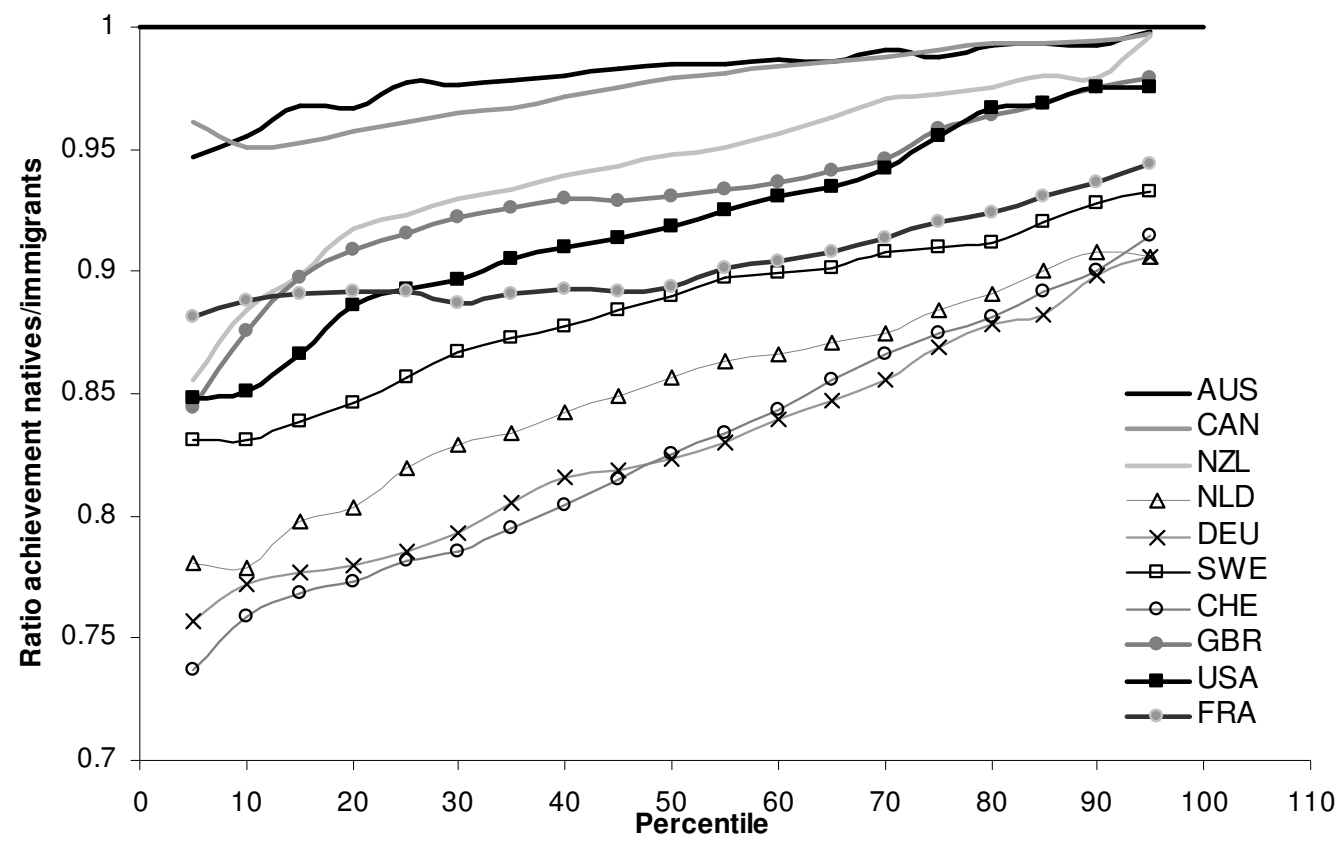

Note: the number 1 subtracted by the ratio is the percent of immigrants' achievement gap compared to natives in the same percentile.

There are also great differences at the top of the distribution. Best performing immigrants achieve similarly to best ranked natives in Australia, Canada, New Zealand, the UK and the USA. Hence, in these countries there is a relative small achievement gap between children with different migration background once the distribution of achievement at the top is concerned. This stands in contrast to the three countries Netherlands, Germany and Switzerland, where even the best achieving immigrants reach scores that are still about 15 percent lower than that of natives at the top of the distribution.

Notable is the steep rise in achievement differences between natives and immigrants once achievement at the bottom scale is concerned in New Zealand, the US and UK. While in these countries immigrants in the $95^{\text {th }}$ percentile do not differ greatly from their native counterparts, pupils with parents born abroad show almost a 15 percent lower achievement than natives once we focus on achievement ratios at the bottom of the distribution. ${ }^{14}$ On the other hand, the achievement ratio shrinks only marginally for increasing percentiles in France.

Taken together, surveys show relative consistent results on educational achievement gaps between immigrants and natives. In traditional countries of 
immigration like Australia, Canada and New Zealand immigrants do not appear to be greatly different from natives. On the other hand, in European countries like the Netherlands, Germany and Switzerland immigrants fare significantly worse than natives. These average achievement differences are great in magnitude as comparisons to grade progression achievement differences and absolute disadvantage showed.

Educational dispersion between immigrants is in general even higher than that between natives. PISA results show that in countries where immigrants' educational achievement is similar to that of natives' immigrants at the bottom of the achievement distribution show only slightly worse performance than their native counterparts. In countries with great immigrants' educational disadvantage achievement differences between immigrants and natives are large especially at the bottom of the achievement distribution. ${ }^{15}$

The next section aims at throwing light on the determinants of immigrants' educational disadvantage.

\section{Determinants of immigrants' achievement}

Educational achievement is greatly related to pupils' socio-economic background. Sub-section 4.1 discusses the different socio-economic background between natives and immigrants that certainly is part of the explanation of immigrants' achievement gaps. However, pupils integration into the 'school environment' is also likely to matter. For countries with great immigrants' educational disadvantage we might assume that immigrants who are highly separated from natives in school perform generally worse than immigrants who are integrated into the host countries' school environment more equally. Sub-section 4.2 discusses the relation between school segregation and immigrants' performance.

Sub-section 4.3 applies regression analysis in order to analyse whether immigrants still face educational disadvantage in the ten countries once it is controlled for pupils' characteristics like SES and school segregation.

\footnotetext{
${ }^{14}$ This explains that immigrants' dispersion in these countries is much greater than that of natives.

${ }^{15}$ The most extreme case is the Netherlands where immigrants in the $5^{\text {th }}$ percentile achieve PISA reading scores that are similar to that of natives in the $75^{\text {th }}$ percentile (see Table A3 in the appendix). However, response rate in the Netherlands was very low so that PISA results for this country need to be interpreted carefully.
} 
4.1 Differences in socio-economic background between natives and immigrants There are a number of variables that could be used to investigate the association between socio-economic background and the native-immigrant achievement gap. The main PISA report (OECD 2001) placed considerable emphasis on the association of scores with indices constructed from principal components analysis of a range of parental characteristics, including occupational indices based on the work of Ganzeboom et al (1992). Obviously these indices cannot be replicated for other surveys that have collected different family background data and we take a much simpler approach in order to make comparisons between the different data sources. ${ }^{16}$ This also has the merit of greater transparency with variables that are relatively easy to comprehend.

One index that proxies parental socio-economic background is pupils' estimation of the number of books at home. This measure of SES has the great advantage of being comparable across countries and immigrant populations (in contrast to migrants' parental education ${ }^{17}$ ). We might assume that children's estimates of books at home are quite unreliable, but the correlation coefficient of 0.93 between the percentage of pupils with more than 100 books at home for PISA and the same share of children for TIMSS shows a great agreement between both surveys.

A straightforward way for estimating socio-economic background differences between immigrants and natives is to calculate the percentage difference between natives and immigrants with more than 100 books at home. Figure 4 gives this percentage difference on the x-axis. ${ }^{18}$ Obviously, differences between natives and immigrants vary greatly across countries. In Canada and New Zealand only about 10 percent more natives than immigrants have more than 100 books at home, while the figure rises to more than 35 percent in Sweden and the Netherlands and is similar to 30 percent in Switzerland and Germany. This pattern reminds of the country ranking on immigrants' educational disadvantage (Table 2) and indeed, once paired with average mean achievement differences between natives and immigrants (y-axis) there seems to be a quite great relationship. Higher SES differences between natives and immigrants are positively related to higher immigrants' achievement gap with a

\footnotetext{
${ }^{16}$ Nevertheless we use the 'International Socio-Economic Index of Occupational Status' (ISEI) for estimating the pupils' composition in school in the later regression framework (Model 3) - see Section 4.3.

${ }^{17}$ See introduction for limitations of our estimation of immigrants' SES.

${ }^{18}$ For figures see Table A4 in the appendix.
} 
correlation coefficient of 0.62 for all OECD countries and 0.82 for the ten high immigration countries. This result suggests that differences between countries regarding educational achievement of immigrants can be partly explained by the different composition of immigrants in these countries.

Figure 4 presents results only for PISA reading, however other surveys' outcomes are similar: the lower share of immigrants with more than 100 books at home is correlated positively with greater immigrants' achievement differences compared to natives in TIMSS math with 0.85 , in TIMSS science with 0.82 and in PIRLS reading with 0.70 for the ten high immigration countries.

Figure 4: Differences in achievement and socio-economic background between natives and immigrants in PISA reading

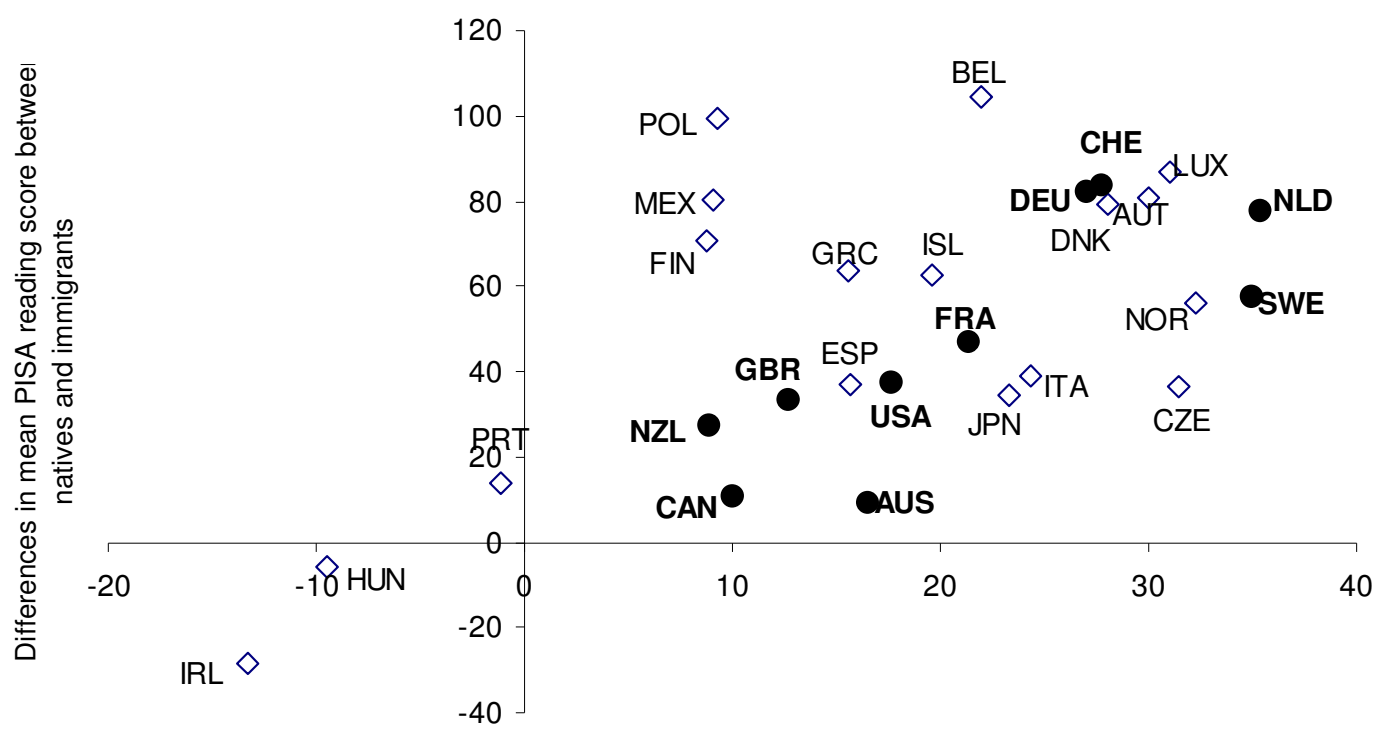

Percent difference between natives and immigrants with more than 100 books at home

Note: For percent differences between natives and immigrants with more than 100 books at home see Table A4 in the appendix.

Besides books at home parental education is another obvious variable to consider since it is closely related to children's learning achievement. However, as discussed before the same level of education but achieved in the host country and in the immigrants' country of origin might refer to quite different educational quality. We estimated the percentage difference between natives and immigrants whose mother completed (upper) ${ }^{19}$ secondary education and correlated this country's share

\footnotetext{
${ }^{19}$ For PISA and PIRLS we compare mothers who completed upper secondary education, for TIMSS data refer to mothers' who completed secondary education.
} 
with the educational achievement gap immigrants suffer in the country. ${ }^{20}$ Also for this measure of socio-economic background differences we find high correlation coefficients between immigrants' achievement and SES gaps with 0.76 for TIMSS maths, 0.67 for PISA reading, 0.65 for PIRLS and 0.62 for TIMSS science.

Taken together, those countries with immigrants' highest educational disadvantage have a migrant composition with highest disadvantage in socioeconomic status. Does this mean that countries' differences in immigrants' achievement gaps are a mere reflection of migrants' socio-economic status in these countries? Or does immigrant status matter beyond SES? The regression framework in sub-section 4.3 examines whether, in which countries and to what extent immigrants' achievement gaps can be explained by countries' socio-economic gap between natives and migrants.

\subsection{School segregation}

Educational achievement differences between immigrants and natives might also derive from immigrants' problems to integrate into the host country. Immigrants are not only different from natives regarding their socio-economic background but also in terms of their cultural attitudes, social contacts, their schooling ambitions, career planning and orientation on return migration. Borjas (1992) argues that it is not only parental influences that determine the child's socio-economic development but that also 'ethnic capital' matters as a whole set of ethnic characteristics to that children in particular ethnic groups are exposed to. Even though immigrants belong to different ethnicities, as a group they might share a similar 'immigrant capital' that is not uniform per se but - at least in some countries - uniform different from that of natives. If we apply furthermore Borjas argumentation on immigrants' school achievement it is the exposure to this 'immigrant capital' that is likely to impact upon children's schooling outcome. The exposure might be transmitted by 'neighbourhood' in terms of residential segregation of ethnicities as found in Borjas (1995) or - closely related to that - by school segregation. ${ }^{21}$ Here, the term 'school segregation' refers to differences in the distribution of immigrants and natives in schools and is conceptually related to the impact of peers' achievement and learning attitudes on general educational outcome at the school level. An immigrant child in a highly

\footnotetext{
${ }^{20}$ For PISA reading pupils' shares are given in Table A5 in the appendix.

${ }^{21}$ Residential segregation often largely determines school segregation as demonstrated in the case of the US (Rivkin 1994).
} 
segregated school with a high percentage of low performing immigrants is very much likely to be pulled to the average of immigrants' achievement, while the same child (with the same socio-economic background) integrated in a not segregated school with a high percentage of well achieving natives is less likely to fall behind in educational achievement.

Hence, school segregation as a measure of conglomeration of immigrant peers might be helpful in explaining immigrants' educational achievement gap. In addition, it is an important factor since it shows how successful countries are in integrating immigrant minorities and hence are opening the opportunities for immigrants to take advantage of a fruitful school environment that is equal to that of their native counterparts.

How to measure school segregation then? Literature on social segregation proposes a range of indices, although the Dissimilarity Index popularised by Duncan and Duncan (1955) has continued to be one of the most widely used. ${ }^{22}$ The formula for the index of dissimilarity, DI, is as follows:

$$
\mathrm{DI}=1 / 2_{1=1}^{\mathrm{N}} \sum \frac{\mathrm{IM}_{\mathrm{i}}}{\mathrm{IM}_{\text {total }}}-\frac{\mathrm{NA}_{\mathrm{i}}}{\mathrm{NA}_{\text {total }}} \mid
$$

where $i$ refers to the school and total to the country. $\mathrm{IM}_{\mathrm{i}}$ denotes the number of immigrants in the school and $\mathrm{IM}_{\text {total }}$ the number of immigrants in the country. $\mathrm{NA}_{\mathrm{i}}$ means the number of natives in the school and $\mathrm{NA}_{\text {total }}$ denotes the number of natives in the country. $\mathrm{N}$ is the number of schools in the country.

The dissimilarity index ranges from 0 to 1 . Its great advantage is that it can be interpreted easily: the dissimilarity index gives the fraction of immigrant pupils that need to be moved to different schools in order to make each school have the same share of immigrants in the country.

However, the estimation of this index with the data available is not unproblematic. First, the data should provide representative samples of data on pupils' immigration status within each school. This criterion is met by PISA since a sample of about 35 students is randomly drawn from the 15 year olds attending the school. However, this contrasts the sample design of TIMSS and PIRLS. These surveys select randomly a single whole class within each school. This is a procedure that is likely to 
result in the data providing a biased estimate of immigration background at the individual school level if, as is common, there is 'setting' for the subjects that are tested in the survey (i.e. children separated into separate classes according to their ability levels). In this case, the ability levels of the selected class will be more homogenous than among all children of that age in the school. Given the correlation between ability and immigration status, the same can be expected to be true of the latter. Given this, we must restrict the estimation of the segregation index to PISA data.

Second, also with PISA data the estimation of the segregation index is problematic due to the stochastic nature of the segregation index and the relative small sample size of pupils (35) drawn in a PISA school. Given the absolute value of the index, any sampling error (hence a proportion of immigrants in the pupils' sample of one school that is different to the proportion of immigrants in the 15 year old school population) in schools with no segregation will result in an upwards bias to the estimator of DI (e.g. Ransom 2000, Cortese et al. 1976). However, the case of no segregation is an extreme case of little practical interest. Ransom (2000) shows that in case of existing segregation, segregation indices distributions are more symmetric. Nevertheless, given small sample sizes of schools and pupils in schools we cannot reject that estimates might show an upward bias of the segregation index.

For the calculation of all national segregation index we need further bear in mind that immigrant groups are not evenly spread over the countries so that the national level of the index is quite superficial. The segregation of immigrants with different countries of origin is also likely to vary greatly. Focusing on different ethnic background Burgess and Wilson (2003) find for England dissimilarity indices (using the same DI) that range from 0.448 for pupils with Chinese ethnic origin to 0.746 for pupils with black African heritage.

However, even though there is a need of some scepticism regarding the appropriateness of the PISA data for the calculation of segregation index, school segregation is likely to be an important explanatory variable for immigrants' achievement gap at least at the individual level where problems of the calculation discussed before impact less than regarding a comparison across countries.

\footnotetext{
${ }^{22}$ This index was recently applied by e.g. Burgess and Wilson (2003) on ethnic segregation in England's schools.
} 
Table 4 presents the segregation index DI together with the number of schools in the PISA sample, the average schools' immigration composition and the percentage of immigrants in the $50^{\text {th }}$ and $90^{\text {th }}$ school percentile (ordered by the share of immigrants in school) by country for PISA reading. The ten countries are ordered by the magnitude of the dissimilarity index.

Comparing the mean and median (P50) immigrant composition shows that throughout all countries most of the schools are attended by a much lower percentage of immigrants than the countries' school mean would imply. On the other hand, the percentage of immigrants in the $90^{\text {th }}$ percentile of the school distribution indicates that immigrants are highly clustered in a small number of schools. While it is difficult to compare the distribution of the overall totals between countries, the segregation indices capture this distribution in a single number. ${ }^{23}$

Table 4: Average school immigrant composition in percent and segregation index, school level in PISA reading

\begin{tabular}{l|c|ccc|c}
\hline \hline & $\begin{array}{c}\text { No. } \\
\text { Schools }\end{array}$ & $\begin{array}{c}\text { Mean } \\
\text { percent of } \\
\text { immigrants } \\
\text { in school }\end{array}$ & $\begin{array}{c}\text { Percent of } \\
\text { immigrants in 50 } \\
\text { percentile (P50) of } \\
\text { school distribution }\end{array}$ & $\begin{array}{c}\text { Percent of } \\
\text { immigrants in the } \\
\mathbf{9 0}^{\text {th }} \text { percentile } \\
\text { (P90) of school } \\
\text { distribution }\end{array}$ & DI \\
\hline USA & 148 & 9.1 & 0 & 40 & 0.647 \\
UK & 362 & 9 & 4 & 20 & 0.616 \\
Canada & 1117 & 13 & 3.4 & 42.4 & 0.602 \\
Netherlands & 100 & 13.2 & 4 & 40 & 0.546 \\
New Zealand & 153 & 14.5 & 8.3 & 40.9 & 0.501 \\
Sweden & 154 & 13.3 & 6.1 & 29.6 & 0.497 \\
Germany & 215 & 16.2 & 11.1 & 33.3 & 0.493 \\
France & 117 & 11.1 & 6.3 & 66.7 & 0.490 \\
Australia & 231 & 23 & 14.3 & 44.4 & 0.479 \\
Switzerland & 282 & 18.7 & 14.3 & 0.400 \\
\hline \hline
\end{tabular}

Note: Countries are ordered by the magnitude of the dissimilarity index. Weighted by school weight. No segregation index for Canada calculated, since schools weight not given. Correlation between Hutchens index and dissimilarity index is 0.97 .

In line with literature (Burgess et al 2000) school segregation is highest in the US for the $\mathrm{DI}^{24}$. Given the DI, almost 65 percent of immigrant pupils in the US compared to more than half in the UK, Canada and Netherlands would need to be moved to achieve their equal representation in all schools. The lowest dissimilarity index is found in Switzerland where still as many as 40 percent of immigrants would need to be shifted to different schools to achieve a proportional representation in each

\footnotetext{
${ }^{23}$ For example, differences between the median and mean percentage of immigrants in schools expressed as a share of the mean percentage is highly correlated with the DI $(0.88)$ across countries.
} 
school. However, eight of the ten countries have a dissimilarity index close or above of 0.5 indicating that countries' integration of immigrant minorities into the educational system appears to be relatively limited.

Even though the dissimilarity index comprises important limitations, the question arises whether the aggregate measure of school segregation is related to immigrants' educational achievement gaps. The correlation of the native-immigration gap in educational achievement for PISA reading (see Table 2) with the dissimilarity index (Table 4) results in a Pearson's correlation coefficient of -0.44 for DI. This indicates a relation in the opposite direction as assumed: on the aggregate country level countries with a greater segregation of immigrants in the school system appear to have a lower educational disadvantage of immigrant pupils.

This result is not necessarily surprising taken into account that besides immigrants' integration into the country's school environment there are other factors impacting upon immigrants' educational disadvantage like parental socio-economic background. Once, these factors are hold constant school segregation might increase immigrants' disadvantage as we would expect. In addition, the focus on the aggregated country level is probably a much too crude measure for explaining immigrants' educational disadvantage.

Hence, for the later regression analysis we estimate the schools' contribution to the (additive) country segregation index.

Each schools' contribution (i) to the aggregated dissimilarity measure (DS) in a country is given by:

$$
\mathrm{DS}_{\mathrm{i}}=\left(\frac{\mathrm{IM}_{\mathrm{i}}}{\mathrm{IM}_{\text {total }}}-\frac{\mathrm{NA}_{\mathrm{i}}}{\mathrm{NA}_{\text {total }}}\right) * 100
$$

This so calculated school's contribution to the additive dissimilarity index can theoretically range from -100 to +100 . A negative value indicates the share of natives that is overrepresented in the school compared to a school where immigrants and natives are distributed evenly based on their representation in the country. A positive value gives the overrepresentation of immigrants in the school.

\footnotetext{
${ }^{24}$ We estimated the school segregation also by using the 'square root index' that satisfies seven desirable properties for a good numerical measure of segregation (Hutchens 2004). This index is correlated with 0.98 with the DI.
} 
The regression analysis in the next section uses this schools' contribution to the DI as an explanatory variable and shows whether immigrants in highly segregated schools face a greater educational disadvantage then their counterparts in other schools when other determinants of achievement at the individual and school level are hold constant.

\subsection{Regression analysis}

Does the socio-economic background gap between migrants and natives explain the country differences in immigrants' achievement gap? This question is of great relevance: in case immigrants' achievement differs to that of natives only due to their on average lower SES, educational policies would solely need to provide additional support for children with a disadvantaged family background. However, if immigrants face additional barriers besides SES, countries' educational policies need to adapt to immigrants' special needs in order to decrease their educational disadvantage.

One great concern regarding educational policies might be school segregation as a measure of countries' capacity to integrate their immigrant population successfully into the schooling system. In how far is school segregation important for explaining educational achievement and in how far does it impact on immigrants' achievement?

Table 5 investigates these issues and presents OLS regression results for three different models for PISA maths, TIMSS maths and PIRLS reading. The focus on maths has the advantage of standardising for subjects between the surveys with similarly old children in secondary school. In all regression models, children's achievement is the dependent variable. The table reports only the estimated effects of those explanatory variables related to immigration background. Native children are the base category. The symbol 'o' denotes that the coefficient of the variable is not significant at the 10 percent level, coefficients without asterisk are significant at the 1 percent level, with one asterisk at the 5 and with two at the 10 percent level. Coding of variables used in the models, summary statistics of these variables by country and the whole regression results for Model 2 for all three surveys are given in the Appendix (Tables A6 - A12). 


\section{Model 1 of Table 5}

The aim of Model 1 is to add to the unconditional results presented in Section 3 by examining educational disadvantage for different types of migrant pupils. In the regression analysis we use three dummies on immigrant status: non-native immigrants, first-generation immigrants and pupils living in a home where the language spoken differs from the test country language. Coefficients of the three explanatory variables are presented in Model 1 of Table 5. The base pupil is native and speaks the test countries' language at home.

Language spoken at home does not capture only immigrants but also other children from different ethnicities. ${ }^{25}$ For that reason, we ran the same regression model by additionally using an interaction variable capturing immigrants who speak another language at home. In general this variable was not significant ${ }^{26}$ so that we chose the more simple regression model presented here.

In all surveys and countries children who speak a foreign language at home receive lower achievement scores than other children. This effect is consistently greatest in Germany with as many as 76 points in PISA and 44 points in TIMSS. However, foreign language appears to impact less on achievement in Canada, Sweden and France and only marginally in Netherlands, where the coefficients are insignificant (TIMSS) or below 20 points (PISA and PIRLS). To help interpret the coefficients, it is worth bearing in mind that the standard deviation in mean achievement is close to 100 for countries and that progression in average scores between $7^{\text {th }}$ and $8^{\text {th }}$ grades in TIMSS maths is on average 30 points.

Once immigration status is concerned, the regression results show a great variation between countries as the unconditional analysis revealed before. In general, PISA and TIMSS results are quite consistent for secondary school pupils' maths achievement, while PIRLS results on primary school immigrants' reading achievement varies more once we compare countries' results between surveys.

In PISA and TIMSS and similar to the presented unconditional results before immigration status does not have a significant negative impact on achievement in Australia and Canada. However, as unconditional results in Section 3 revealed,

\footnotetext{
${ }^{25}$ For PISA maths in general more than 75 percent of children who speak another language at home than that in the test country are immigrants. However, in Canada and Netherlands the share is much smaller (58\% and $27 \%)$.
} 
immigrants face an educational disadvantage in the UK and the USA. Nevertheless, once language is controlled for, immigration does not matter any more in both countries (with the exception of non-natives in the USA in TIMSS). This indicates, that in the UK and USA language skills of immigrants might be the greatest barrier for immigrants to reach similar achievement than their native counterparts.

A similar 'effect' appears in Germany, where immigrants educational disadvantage was large in the before presented unconditional results. However, once language hold constant, first generation immigrants (for PISA and TIMSS) do not differ any more from natives regarding their achievement skills. ${ }^{27}$

On the other hand, in countries like France, Switzerland, Sweden and the Netherlands with low impact of language spoken at home, first generation immigrants and non-native face still a significant educational disadvantage (similar to unconditional results). Throughout all surveys and compared to other countries, almost always both types of immigrant pupils face the greatest educational disadvantage in the Netherlands.

What conclusions can we draw on differences between first-generation migrants' and non-natives' educational achievement gap? In general, controlled for language first-generation pupils outperform greatly non-native pupils. In only four of the 27 regression results presented in Model 1 non-natives performed better than first generation immigrants. Surprising is the result for New Zealand. Non-native immigrants in this country outperform even native students (once language is controlled for) and this result is consistent for TIMSS and PISA.

\section{Model 2}

Sub-section 4.1 showed that there is a great correlation between immigrants' educational disadvantage and the socio-economic gap they face on the country level. Based on the pupils' level Model 2 aims at answering the question whether the socioeconomic gap between immigrants and natives can explain country differences in immigrants educational achievement or whether immigrant status still matters once socio-economic background is controlled for. This is especially interesting for

\footnotetext{
${ }^{26}$ However, in countries where the interaction variable turned out to be significant the value was positive, indicating that immigrants fare better than other children who do not speak the test country's language at home.

${ }^{27}$ Based on educational attainment data and focusing on second generation immigrants Riphahn (2002) receives a contradictory result.
} 
countries where immigrants educational disadvantage remained even if it was controlled for language spoken at home (Model 1).

For answering this question a mix of individual and family characteristics are added to Model 1. We include dummies for children with siblings, children from single-parent families and from 'mixed' family structures. For parental education we include dummies for mothers' education at the secondary and tertiary level as well as a dummy for children with more than 100 books at home. In addition, the gender of the pupils and the area of the school (rural or urban) is controlled for. Table A6 in the Appendix summarises the explanatory variables and their coding used in the regression framework. The base group child in Model 2 is a male native pupil, who speaks the test countries language at home, whose mother has not completed (upper) secondary education and who lives in a home with less than 100 books in an urban area. However, results in Table 5 present only the significant coefficients on the three immigration variables. (See Tables A11 to A13 in the appendix on full results.)

Not surprisingly, regression coefficients for Australia, Canada and New Zealand - the three countries with no or only marginal educational achievement gaps for migrants -do not differ greatly from unconditional results or those presented in Model 1 once it is controlled for socio-economic status and family structure. Since immigrants background is similar to that of natives (see sub-section 3.1), also immigrants' achievement is still similar to that of natives in these countries once controlled for parental background, area and family structure.

However, in the UK and US there appears the slight effect that once SES is controlled for immigrants fare even better than natives. However, the positive coefficients are always smaller than the coefficient for 'language spoken at home' so that only immigrant pupils who speak the test language at home have a marginally higher educational advantage compared to their native counterparts in both countries.

The most interesting results regard countries where immigrants were still different from natives in Model 1. In France, Netherlands, Sweden and Switzerland the impact of immigrant status shrinks greatly once SES is controlled for. Nevertheless, in all four countries in PISA first generation immigrants as well as nonnatives fare still significantly worse in achievement than their native counterparts with similar SES and who speak the same test language at home. This result appears to be consistent with the other two surveys. In TIMSS at least non-native immigrants and in 
PIRLS both types of immigrants face significantly educational disadvantages compared to similar native students in France, Netherlands, Sweden and Switzerland.

In Germany, the immigrant-native gap in language spoken at home and SES explains largely educational achievement gaps at least for PISA and TIMSS. While holding the language variable constant, non-natives fared still worse in Germany for TIMSS and PISA the coefficient of non-natives shrinks by about one-third in PISA and appears to be insignificant in TIMSS once it is additional controlled for SES. However, in PIRLS contrary results appear indicating that primary school immigrants face still a significant educational disadvantage in Germany even if it is controlled for language and SES.

Taken together, consistently across surveys immigrants do not differ greatly from natives in Australia, Canada and New Zealand in general, independent of whether we focus on unconditional results or control for language spoken at home, SES, family structure and area. A foreign language spoken at home seems to explain a large amount of immigrants' achievement differences in the UK and the USA. However, consistently across surveys ${ }^{28}$ neither SES nor foreign language can explain the total amount of immigrants' educational disadvantage in the Netherlands, France, Sweden and Switzerland. In these countries immigrants with the same socio-economic background and the same language spoken at home than natives achieve still worse than their native counterparts. For all four countries about 60 percent $^{29}$ of the achievement gap between immigrants and natives remains unexplained by Model 2 in PISA, while it is about 40 percent for the countries Netherlands, Sweden and Switzerland covered by TIMSS. ${ }^{30}$

\footnotetext{
${ }^{28}$ If we facilitated Model 2 by creating a dummy for immigrants as a whole (instead separating between non-natives and first generation immigrants) the consistency of survey results is even much clearer. Throughout all surveys immigrants are not significantly different from natives in Australia, Canada, New Zealand, UK and the USA if controlled for parental background. In France, the Netherlands, Sweden and Switzerland immigration still matters conditional on SES. Only in Germany survey results vary: while immigration status is insignificant for determining achievement in PISA and TIMSS, immigrants' achievement in PIRLS reading is still worse than that of their native counterparts with similar family background.

${ }^{29}$ For receiving this result we decompose achievement differences between natives and immigrants into an explained and residual component (Oaxaca 1973). The percentage gives the unexplained component as a share of the total difference in achievement between immigrants and natives.

${ }^{30}$ While in PISA and TIMSS countries do rather not differ regarding the unexplained share in the achievement gap this is different for PIRLS. With this survey the unexplained achievement gap between natives and immigrants is 35 percent for Sweden, 45 percent for France, 55 percent in Germany and 69 percent in the Netherlands.
} 


\section{Model 3}

As argued in Sub-section 4.2, not only parental background impacts upon achievement but in addition special immigrant characteristics (like schooling ambitions or cultural attitudes) pupils are exposed to. This might be the reason for the considerable unexplained share of immigrants' educational achievement gap in some countries that resulted from Model 2. Hence, Model 3 questions whether a higher concentration of immigrant peers in schools is related to greater immigrants' educational disadvantage.

For examining this question we calculate a variable in PISA, that gives each school's share of natives who are over-represented in the school (negative value) or share of over-represented immigrants (positive value) that would need to be shifted in order to achieve a country proportional representation of immigrants in the school. More precise, the calculation formula estimates the contribution of each school to the before described national $\mathrm{DI}^{31}$. However, it is important to note that the so calculated contribution of the school to the national DI might capture considerable 'noise' given that the pupils' sample size ${ }^{32}$ per school is generally not greater than 35 and that also the school sample size is relatively small for some countries in PISA. ${ }^{33}$

Adding only the schools' DI contribution variable to Model 2 could lead to an overestimation of its impact, since schools with great shares of immigrants might be attended by pupils with an on average lower socio-economic background than schools with an over-representation of natives. In order to control for this 'schools' socioeconomic composition', we add a further variable to the model that captures the schools' average 'International Socio-Economic Index of Occupational Status' $\left(\right.$ ISEI) ${ }^{34}$ of pupils' parents.

Table 5 shows the results. For all countries a higher average of the schools 'socio-economic position' is also related to a significantly (1 percent level) higher achievement of the pupil attending this school even though it is controlled for pupils' socio-economic background (variable school ISEI).

\footnotetext{
${ }^{31}$ We prefer the DI to the SRI given its relative clear interpretation. However, since indices are highly correlated, results do not change if the SRI is applied.

${ }^{32}$ Sample sizes are even smaller for PISA maths, since only half of the pupils who participated in PISA reading participated also in the PISA maths test. Hence, the dissimilarity index was estimated by using PISA reading data. Then we created a school file with the dissimilarity index and merged this file with the PISA maths file used for the regression analysis.

${ }^{33}$ See Table 4 for the school sample size by country.

${ }^{34}$ The ISEI is based on education, income and age of parental occupational groups (see Ganzeboom 1992). For summary statistics see Table A6 in the appendix.
} 
However, what is the impact of highly segregated schools? In eight of the ten countries covered by PISA the schools dissimilarity contribution is significant at least at the 5 percent level. In seven of these countries an overrepresentation of immigrants in the school is related to lower achievement even if controlled for pupils' and schools' socio-economic background. In only one of these countries - Australia - the dissimilarity contribution is positive, indicating that a higher share of immigrants has a positive impact on achievement results (5 percent significance level). This result might reflect that the 'immigrant capital' in Australia is favourable ${ }^{35}$.

In the USA, the UK and New Zealand children in schools where immigrants are over-represented with one percent achieve about 5 to 10 points less than their counterparts in schools with a representative distribution of immigrants for the country population. Great are achievement differences of these pupils in Switzerland, Canada and Germany where differences amount to as many as 25 to 30 points. Nevertheless, even though we controlled for schools' and pupils' SES, these point differences need to be interpreted carefully. The educational system in Germany and Switzerland is shaped by a hierarchical school structure. Immigrant students are likely to attend the less prestigious school tracks, where educational achievement in general is lower than in schools with higher prestigious. Hence, in both countries the schools' dissimilarity value might be correlated greatly with the school track pupils attend and results present therefore also the generally lower achievement in schools at the bottom end of the school hierarchy.

Nevertheless, the result on school segregation indicates that both, natives and immigrants, fare worse if immigrants are over-represented in the school. We ran the same model adding an interaction variable between the schools' dissimilarity value and migration. This variable was in all but one case ${ }^{36}$ insignificant, confirming that generally the schools' segregation 'effect' impacts negatively on both types of pupils.

The results are likely to confirm the before discussed thesis (Sub-section 3.2), that immigrants' lower integration in the host countries' school environment gains additional explanatory power besides SES for explaining educational outcomes.

\footnotetext{
${ }^{35}$ Table A5 in the appendix shows, that Australia is the only country where more immigrants' than natives' mothers have completed upper secondary education for PISA reading.

${ }^{36}$ In the USA pupils in highly segregated schools in general but even more immigrants in highly segregated schools fare worse than pupils in other schools, if it is controlled for the schools' and pupils' SES (10 percent significant level only).
} 
Nevertheless, also less favourable capital of natives who attend highly segregated schools might impact upon lower schools' achievement outcomes.

However, can school segregation regarding average pupils' socio-economic background or immigrants school segregation explain the great share of immigrant educational disadvantage that remained unexplained in some countries in Model 2? In contrast to results for PISA in Model 2, once it is controlled for school segregation in three of the four countries with high immigrants' disadvantage, France, Sweden and Switzerland, first generation immigrants do not any more fare significantly worse than natives. In addition, also point differences for non-natives shrink by a third (France, Switzerland and Netherlands) or fall into insignificance (Sweden). This result indicates that school segregation does matter for explaining immigrants' lower educational achievement.

Taken together, the regression analysis shed light on variation in achievement between different groups of immigrants (Model 1), the impact of SES on immigrants' achievement gap (Model 2) and the influence of school segregation (Model 3). TIMSS and PISA results for about 14 to 15 year-olds appear to be relative consistent, while PIRLS results on reading achievement of primary school children differ more greatly compared to the other two surveys.

For Australia, Canada and New Zealand we find that immigrants do not differ greatly from natives regarding their educational achievement. Achievement gaps between natives and migrants in the UK and the USA diminish greatly once it is controlled for the language spoken at home. This indicates, that it is especially pupils with different language skills that drive immigrants' achievement gaps in these countries. In Germany, immigrants seem to differ from natives mainly due to their language spoken at home and their lower socio-economic status. However, migration matters still in France, the Netherlands, Sweden and Switzerland if it is controlled for language and parental background. Adding a variable to the model that captures the dissimilarity in immigrants distribution between schools decreases greatly the significance of the migration variables in these countries. Hence, in these four countries, especially socio-economic background but also the higher clustering of immigrants in schools explains the relatively large educational disadvantage of pupils whose parents were born abroad. 
Table 5: OLS regression results showing differences in achievement between migrants and natives unconditional (model 1) and conditional on parental background (model 2) and on parental background and school segregation (model 3) for PISA maths, TIMSS maths $\left(8^{\text {th }}\right.$ graders) and PIRLS; selection of OLS regression results with dependent variable pupils' achievement

\begin{tabular}{|c|c|c|c|c|c|c|c|c|c|c|c|c|}
\hline Model & Survey & Migration & AUS & $\mathbf{C A N}$ & FRA & DEU & NLD & NZL & SWE & CHE & GBR & USA \\
\hline \multirow{9}{*}{1} & \multirow{3}{*}{ PISA } & First generation & $\mathrm{O}$ & $\mathrm{O}$ & -23 & $\mathrm{O}$ & -70 & $\mathrm{O}$ & -37 & -35 & $\mathrm{O}$ & $\mathrm{O}$ \\
\hline & & Non native & $\mathrm{O}$ & $\mathrm{O}$ & -63 & -36 & -102 & +25 & -45 & -71 & $\mathrm{O}$ & $\mathrm{O}$ \\
\hline & & Language & -19 & $-10 *$ & -32 & -76 & $-14 * *$ & -51 & -31 & -42 & -48 & -81 \\
\hline & \multirow{3}{*}{ TIMSS } & First generation & $\mathrm{O}$ & $\mathrm{O}$ & - & $\mathrm{O}$ & $-22 * *$ & -24 & $-12 * *$ & -26 & $\mathrm{O}$ & $\mathrm{O}$ \\
\hline & & Non native & $+17 *$ & $\mathrm{O}$ & - & $-21 *$ & -53 & $+24 *$ & -37 & -41 & $\mathrm{O}$ & -21 \\
\hline & & Language & -39 & -18 & - & -44 & $\mathrm{O}$ & -36 & $-17 *$ & -41 & -36 & -43 \\
\hline & \multirow{3}{*}{ PIRLS } & First generation & - & +9 & -17 & -21 & -43 & +19 & -16 & - & $+11 * *$ & $\mathrm{O}$ \\
\hline & & Non native & - & -21 & -28 & -42 & -30 & $+14^{*}$ & -43 & - & -45 & -39 \\
\hline & & Language & - & -41 & -31 & -40 & -17 & -69 & -28 & - & -47 & -48 \\
\hline \multirow{9}{*}{ controlled for SES } & \multirow{3}{*}{ PISA } & First generation & $\mathrm{O}$ & $\mathrm{O}$ & -16 & $\mathrm{O}$ & -47 & $\mathrm{O}$ & $-28 *$ & -26 & $\mathrm{O}$ & $\mathrm{O}$ \\
\hline & & Non native & $\mathrm{O}$ & $\mathrm{O}$ & -46 & $-23 *$ & -78 & $+18 *$ & $-28 *$ & -48 & $\mathrm{O}$ & $+23 * *$ \\
\hline & & Language & $-14 *$ & $\mathrm{O}$ & -26 & -56 & $-15 * *$ & -43 & $-31 *$ & -32 & -36 & -57 \\
\hline & \multirow{3}{*}{ TIMSS } & First generation & $\mathrm{O}$ & $\mathrm{O}$ & - & $\mathrm{O}$ & $\mathrm{O}$ & -21 & $\mathrm{O}$ & -19 & $+13 * *$ & $\mathrm{O}$ \\
\hline & & Non native & +16 & $\mathrm{O}$ & - & $\mathrm{O}$ & $-39 *$ & +23 & -28 & -26 & $+19 * *$ & $\mathrm{O}$ \\
\hline & & Language & -29 & $-15^{*}$ & - & -39 & $\mathrm{O}$ & -24 & $\mathrm{O}$ & -34 & -26 & -30 \\
\hline & \multirow{3}{*}{ PIRLS } & First generation & - & $+11 *$ & $-7 * *$ & -13 & -35 & +17 & $-18 *$ & - & +15 & - \\
\hline & & Non native & - & -18 & -18 & -32 & -22 & $\mathrm{O}$ & -29 & - & -32 & - \\
\hline & & Language & - & -39 & -25 & -31 & -14 & -50 & -23 & - & -40 & - \\
\hline \multirow{5}{*}{$\begin{array}{c}\mathbf{3} \\
\text { controlled for SES } \\
\text { family structure and } \\
\text { schools' } \\
\text { contribution to } \\
\text { dissimilarity index }\end{array}$} & \multirow{5}{*}{ PISA } & First generation & $\mathrm{O}$ & $\mathrm{O}$ & $\mathrm{O}$ & $\mathrm{O}$ & $-17 *$ & $\mathrm{O}$ & $\mathrm{O}$ & $\mathrm{O}$ & $\mathrm{O}$ & $+24 *$ \\
\hline & & Non native & $\mathrm{O}$ & $\mathrm{O}$ & -36 & $\mathrm{O}$ & -49 & +20 & $\mathrm{O}$ & -31 & $\mathrm{O}$ & $+27 *$ \\
\hline & & Language & $-14^{*}$ & $\mathrm{O}$ & $\mathrm{O}$ & -44 & $\mathrm{O}$ & -40 & -30 & -33 & -24 & -39 \\
\hline & & Schools' ISEI & 2.6 & 2.0 & 3.0 & 4.6 & 5.2 & 2.5 & 2.3 & 2.5 & 3.6 & 3.7 \\
\hline & & School segregation & $+7 *$ & -27 & -16 & -30 & $\mathrm{O}$ & -9 & $\mathrm{O}$ & -25 & $-5^{*}$ & -8 \\
\hline
\end{tabular}

Note: The base group student for model 2 and 3 is male, has at least one parent who is born in the country of the test and speaks the language of the test. First generation migrant is born in the test country and both parents are born abroad; a non-native and his/her parents are born abroad. O denotes variable not significant at 10 percent level.

** means significance at 10 and * significance at 5 percent level, numbers without asterisk are significant at 1 percent level. Results of model 2 are given in Appendix for all three surveys. In PIRLS the variable on education was not administered in USA. Results for TIMSS for GBR refer only to Scotland in Model 2. Correlation between schools socio economic background and school segregation is 0.08 . 


\section{Conclusion}

How do immigrants differ from natives regarding educational achievement and do we receive robust results across surveys?

For answering these questions we order the results of this analysis by three different reasons (discussed in detail in the introduction) why we expect immigrants' achievement to be different from that of natives.

First, immigrants' socio-economic background might be different from that of natives. At the country level of analysis, we found consistently across surveys that the lower the socio-economic background of immigrants is compared to natives in the country the bigger is immigrants' educational disadvantage in this country. In Australia, Canada and New Zealand immigrants' SES is similar to that of natives. Hence, surveys show consistently no or only marginal educational disadvantage of immigrants for these three countries. On the other hand, in the Netherlands, Germany and Switzerland immigrants' composition is much less favourable than that of natives, so that in these countries immigrants fare much worse than natives regarding educational achievement.

Nevertheless, once we switch from the country to the individual level by applying an OLS regression framework we find that family background is not the only factor that impacts upon immigrants' achievement. Relatively consistently across surveys in France, the Netherlands, Sweden and Switzerland immigration still matters even if pupils' socio-economic background is hold constant.

What else might impact on immigrants' educational achievement then?

Second, immigrants' educational disadvantage might derive from their problems of integration into the host country. One aspect of the integration issue is the pupils' capacity to communicate in the language of the host country. Regression analysis showed consistently across surveys that speaking a foreign language at home decreases pupils' achievement greatly in all countries compared.

Another aspect of integration is the time immigrants live in the host country. We expect pupils who were born and grew up in the host country (first-generation immigrants) to be better integrated into their host society than newly arrived immigrants (non-native immigrants). On the aggregated country level but also by applying the OLS regression framework, results showed that first-generation 
immigrants fared much better than non-native immigrants in all countries with the exception of New Zealand. Again, this result was greatly consistent across surveys.

The last aspect regarding immigrants' integration we examined was school segregation as a measure of conglomeration of immigrant peers and as an indicator for how successful countries are in integrating immigrant minorities in the school environment. In Canada, France, Germany, New Zealand, Switzerland, the UK and the USA pupils in schools with an over-representation of immigrants (compared to the national share of 15 year old immigrants) fared worse than pupils in other schools even if pupils' and schools' socio-economic background were hold constant.

Obviously, high clustering of immigrants in some schools is neither favourable for the educational achievement of immigrants nor natives attending these schools. (This result however is only based on PISA data since the sample design of the other two surveys did not allow for constructing a segregation index.)

Controlling for school segregation decreased immigrants' educational disadvantage in France, the Netherlands, Sweden and Switzerland where socioeconomic background differences between the two groups of children could not explain the whole immigrants' educational disadvantage.

Third, the process of selection of immigrants is likely to impact upon their achievement results. Immigration control but also the self-selection of immigrants determines the characteristics and motivations of immigrants. In this paper it was not possible to examine this selection issue. Our data lack even the most basic variable for doing so, the immigrants' country of origin. However, achievement data allow for examining educational dispersion of immigrants and natives separately indicating how different immigrants are compared to natives. This perspective also emphasises that "immigrant" is not equal to "immigrant" in one country. TIMSS and PISA results showed that immigrants show generally higher educational dispersion than natives. Hence, they differ even more in their educational outcomes than their native counterparts. In countries where immigrants' educational disadvantage is small immigrants at the bottom of the achievement distribution show only slightly worse performance than their lowest achieving native counterparts. However, immigrants' achievement at the bottom of their achievement distribution is much lower than that of lowest performing natives in those countries where immigrants face considerable educational disadvantages. Hence, immigrants fall even far behind the worst achieving natives in Switzerland, Germany and the Netherlands. This result is 
concerning since these immigrants' chances to catch up and to integrate into the host countries' labour markets are rather small.

The results of the analysis lead to some clear policy implications for fostering immigrants' educational achievement.

The promotion of language skills of immigrant students speaking a foreign language is important in all countries we focused on. In countries, where socioeconomic background differences are great between immigrants and natives (like Switzerland, Netherlands, Germany, France and Sweden), promoting all pupils with unfavourable family background would benefit greatly also immigrants. In addition, decreasing school segregation is likely to have a positive outcome on pupils' achievement in general and for some countries it might additionally decrease immigrants' educational achievement gap. Furthermore, in Netherlands, Germany and Switzerland a general promotion of the lowest low performing students would greatly help those immigrants who are gathered around the bottom and lost end of the achievement distribution. 


\section{References}

R. Bedford (2003), 'The politicisation of immigration' (New Zealand), http://migrationinformation.org.

A. Blum, H. Goldstein and F. Guerin-Pace (2001), 'An analysis of international comparisons of adult literacy', Assessment in Education, vol. 8, no. 2.

G. Borjas (1992), 'Ethnic capital', in Borjas, Haven's Door

G. Borjas (1995), 'Ethnicity, Neighborhoods, and Human-Capital Externalities', The American Economic Review, Vo. 85, No. 3, pp. 365-390.

G. Brown and J. Micklewright (2003), 'Using TIMSS, PISA and IALS: A View from the Outside', UNESCO Institute for Statistics, Montreal.

S. Burgess and D. Wilson (2003), 'Ethnic segregation in England's schools', CMPO Working Paper Series No. 03/086.

S. Castles and M. Miller (2003), 'New Ethnic Minorities and Society', The Age of Migration. International Population Movements in the Modern World, third edition.

C. Cortese, R. Frank Falk and J. Cohen (1976), 'Further considerations on the methodological analysis of segregation indices', American Sociological Review, Vol. 41, pp. 630-637.

F. Demie (2001), 'Ethnic and gender differences in educational achievement and implications for school improvement strategies', Educational Research, vol. 43, no.1, pp. 91-106.

O. Duncan and B. Duncan (1995), 'A methodological analysis of segregation indexes’, American Sociological Review, vol. 20, pp. 210-217.

H. Entorf and N. Minoiu (2004), 'PISA results: what a difference immigration law makes', IZA Discussion Paper, No. 1021.

H.B.G. Ganzeboom, P. De Graaf and D.J. Treiman (with J. De Leeuw) (1992), 'A standard international socio-economic index of occupational status', Social Science Research, Vol. 21 (1), pp. 1-56.

J. Glick and M. White (2003), 'The academic trajectories of immigrant youths: analysis within and across cohorts', Demography, vol. 40, no. 4, pp. 759-783.

R. Hutchens (2004), 'One measure of segregation', International Economic Review 45(2): 555-578.

C. Inglis (2002), ‘Australia’s Transformation’, http: Iwww.migrationsinformation.org 
D. Massey and N. Denton (1988), 'The dimension of residential segregation', Social Forces, Vol. 67, pp. 281-315.

I. Mullis, M. Martin, E. Gonzales and A. Kennedy (2003), PIRLS 2001 International Report, Boston College.

I. Mullis, M. Martin, E. Gonzalez, K. Gregory, R. Garden, K. O’Connor, S. Chrostowski, T. Smith (2000), TIMSS 1999 International Mathematics Report, Boston College.

Oaxaca R. L. (1973) 'Male-Female Wage Differentials in Urban Labour Markets', International Economic Review, Vol. 14, pp. 529- 536.

OECD and Statistics Canada (2000), Literacy in the Information Age - Final Report of the International Adult Literacy Survey, OECD, Paris.

OECD (2001), Knowledge and Skills for Life - First results from PISA 2000, OECD, Paris.

OECD (2003), Trends in International Migration, OECD, Paris.

OECD and UNESCO Institute for Statistics (2003) Literacy Skills for the World of Tomorrow - Further results from PISA 2000, OECD, Paris

J. Ours and J. Veenman, 'The educational attainment of second generatin immigrants in the Netherlands', OSA working paper, WP2001-11.

M Ransom (2000), 'Sampling distributions of segregation indexes', Sociological Methods \& Research, Vol. 28, No. 4, pp. 454-475.

B. Ray (2002), 'Policy legacies, new directions , and future chalanges' (Canada), http: llwww.migrationsinformation.org.

R. Riphahn (2002), 'Cohort effects in the educational attainment of second generation immigrants in Germany: an analysis of census data', IZA working paper.

S. Rivkin (1994), 'Residential segregation and school integration?, Sociology of Education, vol. 67, pp. 279-292.

C. Schmid (2001), 'Educational achievement, language-minority students, and the new second generation', Sociology of Education, vol. 74, pp. 71-87.

UNICEF (2002), A league table of educational disadvantage in rich nations, Innocenti Report Card No. 4, UNICEF Innocenti Research Centre, Florence. 
Table A1: Share of immigrants in survey sample and foreign born population by country

Appendix

\begin{tabular}{lccc|c}
\hline \hline & PISA & $\begin{array}{c}\text { Educational survey data } \\
\text { TIMSS }\end{array}$ & PIRLS & OECD data \\
\hline & $\mathbf{1 5}$ year olds & $\mathbf{8}^{\text {th }}$ graders & $\mathbf{4}^{\text {th }}$ graders & $\begin{array}{c}\text { Foreign born as share of } \\
\text { population }\end{array}$ \\
\hline Australia & 23 & 24.1 & & 23.6 \\
Canada & 20.3 & 17.4 & 23.4 & 17.4 \\
Switzerland & 20 & 20.3 & & - \\
New Zealand & 19.6 & 16.2 & 19.7 & 19.5 \\
Germany & 15.2 & 12.4 & 14.6 & - \\
USA & 12.9 & 10.4 & 20.1 & 10.4 \\
Netherlands & 12 & 11.1 & 10.1 & 10.1 \\
France & 10.9 & & 15.4 & 10 \\
Sweden & 10.6 & 9.2 & 11.4 & - \\
UK & 8.7 & 13.8 & 13.8 & - \\
\hline \hline
\end{tabular}

Source: own calculations for immigrants' share in educational surveys, OECD 2003. Immigrants refer to non-natives and first generation immigrants. Data on foreign born population refer to 1999 for France, 1996 for Canada and to 2000 for all other countries. Survey data and OECD data are not directly comparable, since survey data focus on pupils whose parents where born abroad while OECD data captures the share of foreign born as a share of the total population.

Table A2: Correlation of differences in scores between native and immigrant pupils between surveys

\begin{tabular}{cccccccc}
\hline \hline & & \multicolumn{3}{c}{ PISA } & \multicolumn{2}{c}{ TIMSS } & PIRLS \\
& & Reading & Maths & Science & Maths & Science & Reading \\
\hline \multirow{2}{*}{ PISA } & Reading & 1 & & & & & \\
& Maths & 0.98 & 1 & & & & \\
& Science & 0.96 & 0.97 & 1 & & & \\
TIMSS & Maths & 0.85 & 0.82 & 0.80 & 1 & & 1 \\
& Science & 0.85 & 0.80 & 0.78 & 0.97 & 1 & \\
PIRLS & Reading & 0.84 & 0.89 & 0.80 & 0.69 & 0.67 & 1 \\
\hline \hline
\end{tabular}

Note: Correlation is based on all observations that are not missing in the two surveys correlated. TIMSS data refer to 95 for all countries but USA (1999).

Table A3: P95-P5 for natives and immigrants by country for PISA reading and TIMSS maths achievement

\begin{tabular}{lcccc}
\hline \hline P95-P5 & \multicolumn{2}{c}{ PISA read } & \multicolumn{2}{c}{ TIMSS maths } \\
& Natives & Migrants & Natives & Migrants \\
\hline Australia & 325 & 343 & 257 & 273 \\
Canada & 305 & 318 & 239 & 243 \\
France & 297 & 302 & & \\
Germany & 316 & 337 & 246 & 282 \\
Netherlands & 276 & 299 & 243 & 236 \\
New Zealand & 342 & 390 & 285 & 320 \\
Sweden & 294 & 312 & 224 & 249 \\
Switzerland & 310 & 345 & 208 & 264 \\
UK & 323 & 365 & 275 & 267 \\
USA & 342 & 375 & 280 & 309 \\
\hline \hline
\end{tabular}


Table A4: PISA reading achievement: percentiles for natives and immigrants by country

\begin{tabular}{lllllllll}
\hline \hline \multirow{2}{*}{ Australia } & & $\mathbf{q 5}$ & $\mathbf{q 1 0}$ & $\mathbf{q 2 5}$ & $\mathbf{q 5 0}$ & $\mathbf{q 7 5}$ & $\mathbf{q 9 0}$ & $\mathbf{q 9 5}$ \\
\hline \multirow{2}{*}{ Canada } & Native & 361 & 398 & 461 & 536 & 604 & 657 & 686 \\
& Immigrant & 342 & 380 & 451 & 528 & 596 & 652 & 685 \\
\hline \multirow{2}{*}{ France } & Native & 377 & 415 & 477 & 543 & 602 & 653 & 682 \\
& Immigrant & 362 & 395 & 459 & 531 & 596 & 649 & 680 \\
\hline \multirow{2}{*}{ Germany } & Native & 352 & 389 & 452 & 517 & 575 & 622 & 649 \\
& Immigrant & 310 & 345 & 403 & 462 & 529 & 582 & 613 \\
\hline \multirow{2}{*}{ Netherlands } & Native & 340 & 378 & 445 & 510 & 574 & 627 & 656 \\
& Immigrant & 258 & 292 & 350 & 420 & 499 & 563 & 595 \\
\hline \multirow{2}{*}{ New Zealand } & Native & 392 & 426 & 487 & 549 & 601 & 644 & 668 \\
& Immigrant & 306 & 332 & 400 & 470 & 531 & 585 & 605 \\
\hline \multirow{2}{*}{ Sweden } & Native & 352 & 395 & 469 & 544 & 610 & 664 & 693 \\
& Immigrant & 301 & 350 & 433 & 516 & 593 & 650 & 691 \\
\hline \multirow{2}{*}{ Switzerland } & Native & 365 & 403 & 464 & 529 & 586 & 633 & 660 \\
\hline \multirow{2}{*}{ UK } & Immigrant & 304 & 335 & 398 & 471 & 533 & 588 & 616 \\
\hline \multirow{2}{*}{ USA } & Native & 348 & 386 & 449 & 518 & 578 & 629 & 658 \\
& Immigrant & 257 & 293 & 351 & 428 & 505 & 567 & 601 \\
\hline \hline
\end{tabular}

Table A5: Socio-economic background for natives and immigrants and differences between both groups of children in PISA

\begin{tabular}{lllllll} 
& \multicolumn{2}{l}{ More than 100 books at home } & \multicolumn{3}{c}{$\begin{array}{l}\text { Percent mothers who finished } \\
\text { upper secondary education }\end{array}$} \\
& Natives & Migrants & Difference & Natives & Migrants & Difference \\
\hline Switzerland & 55 & 27 & -28 & 57 & 29 & -27 \\
Germany & 54 & 27 & -27 & 73 & 29 & -44 \\
Netherlands & 46 & 11 & -35 & 43 & 22 & -21 \\
Sweden & 65 & 30 & -35 & 78 & 64 & -14 \\
France & 47 & 25 & -21 & 66 & 33 & -33 \\
USA & 49 & 31 & -18 & 86 & 50 & -36 \\
UK & 50 & 37 & -13 & 75 & 52 & -23 \\
New Zealand & 57 & 48 & -9 & 66 & 65 & -1 \\
Canada & 57 & 47 & -10 & 84 & 78 & -6 \\
Australia & 64 & 48 & -16 & 66 & 70 & 3 \\
\hline \hline
\end{tabular}

Note: Countries are ordered by differences in mean scores between natives and immigrants in PISA reading (see Table 2). 
Table A6: Variables and coding for regression analysis

\begin{tabular}{|c|c|c|c|}
\hline $\begin{array}{l}\text { Model } \\
\text { used }\end{array}$ & & Variable & Coding of variable \\
\hline \multirow{3}{*}{$1,2,3$} & \multirow{3}{*}{$\begin{array}{l}\text { Dependent } \\
\text { variables }\end{array}$} & PISA & Maths test score \\
\hline & & TIMSS & Maths test soore \\
\hline & & PIRLS & Reading test score \\
\hline \multirow{4}{*}{$1,2,3$} & \multicolumn{3}{|c|}{ Independent variables } \\
\hline & & Non-native & $1=$ parents and pupil born abroad, $0=$ rest \\
\hline & Migration & First generation migrant & $\begin{array}{l}1=\text { parents born abroad, pupil born in test } \\
\text { country, } 0=\text { rest }\end{array}$ \\
\hline & & Language spoken at home & $1=($ almost $)$ always foreign language, $0=$ rest \\
\hline 2,3 & Gender & gender & Boys $=0$, girls $=1$ \\
\hline 2,3 & $\begin{array}{c}\text { SE } \\
\text { (Parents' socio- } \\
\text { economic } \\
\text { background) } \\
\text { and }\end{array}$ & $\begin{array}{c}\text { Books in household } \\
\text { (mother has education below } \\
\text { upper secondary) } \\
\text { Mother above (upper) } \\
\text { secondary education } \\
\text { Mother tertiary education } \\
\text { Education missing (edumis) }\end{array}$ & $\begin{array}{l}0=0-100 \text { books, } 1=\text { more than } 100 \text { books } \\
\text { (Control group: } \text { mother did not complete } \\
\text { secondary education) } \\
1=\text { mother completed at least upper secondary } \\
\text { education education, } 0=\text { rest } \\
1=\text { mother completed tertiary education, } 0=\text { rest } \\
0=\text { data available, } 1=\text { data missing }\end{array}$ \\
\hline 2,3 & FT (Family type) & $\begin{array}{c}\text { Sibling } \\
\text { Single parent } \\
\text { Other family type }\end{array}$ & $\begin{array}{l}0=\text { child without siblings, } 1=\text { other } \\
1=\text { child raised in single parent family, } 0=\text { rest } \\
1=\text { other family type than single or nuclear family } \\
\text { (control group), } 0=\text { rest }\end{array}$ \\
\hline 2,3 & Area & $\begin{array}{c}\text { Area } \\
\text { RegMis, Location missing: }\end{array}$ & $\begin{array}{l}0=\text { urban or suburban, } 1=\text { rural } \\
0=\text { data available }, 1=\text { data missing }\end{array}$ \\
\hline 3 & School ISEI & School ISEI & $\begin{array}{l}\text { Continuous, schools' average International } \\
\text { Socio-Economic Index of Occupational Status }\end{array}$ \\
\hline 3 & Dissimilarity index & Dissimilarity school & $\begin{array}{l}\text { Continuous, share of natives (negative value) or } \\
\text { immigrants (positive value) over-represented in } \\
\text { school given national level }\end{array}$ \\
\hline
\end{tabular}

Note: Model used gives the model where variables were used in the regression framework (see Table 5). In PIRLS and PISA mothers' education refers to the completion of upper secondary education, in TIMSS to the completion of secondary education. In PISA and TIMSS single parent families refer to children who live with only one of the following guardians: mother, father, male guardian or female guardian. In PIRLS single parent family refer to families where children live solely with one adult. In this survey no data are available on other family types. 
Table A7: PISA summary statistics

\begin{tabular}{|c|c|c|c|c|c|c|c|c|c|c|c|c|c|c|c|c|}
\hline & Maths & gender & sibling & Single & other & $\begin{array}{l}\text { First } \\
\text { Gen }\end{array}$ & $\begin{array}{l}\text { Non } \\
\text { Native }\end{array}$ & language & $\begin{array}{l}\text { Second } \\
\text { educat }\end{array}$ & $\begin{array}{l}\text { Tertiar } \\
\text { educat }\end{array}$ & $\begin{array}{c}\text { Educat } \\
\text { miss }\end{array}$ & books & Area & $\begin{array}{c}\text { Area } \\
\text { mis }\end{array}$ & $\begin{array}{l}\text { School } \\
\text { ISEI }\end{array}$ & DSC \\
\hline Australia & 533.32 & 0.46 & 0.96 & 0.16 & 0.11 & 0.11 & 0.12 & 0.18 & 0.68 & 0.29 & 0.04 & 0.60 & 0.14 & 0.00 & 45.4 & 0.02 \\
\hline Canada & 533.00 & 0.50 & 0.94 & 0.15 & 0.13 & 0.10 & 0.10 & 0.12 & 0.82 & 0.48 & 0.03 & 0.56 & 0.00 & 1.00 & 45.7 & 0.04 \\
\hline France & 517.15 & 0.52 & 0.92 & 0.14 & 0.12 & 0.09 & 0.02 & 0.05 & 0.61 & 0.28 & 0.07 & 0.44 & 0.26 & 0.11 & 43.4 & -0.01 \\
\hline Germany & 489.80 & 0.51 & 0.88 & 0.14 & 0.11 & 0.05 & 0.10 & 0.07 & 0.64 & 0.12 & 0.14 & 0.50 & 0.31 & 0.11 & 43.9 & 0.03 \\
\hline Netherlands & 563.82 & 0.49 & 0.96 & 0.10 & 0.07 & 0.08 & 0.04 & 0.19 & 0.39 & 0.15 & 0.06 & 0.41 & 0.11 & 0.06 & 47.0 & 0.06 \\
\hline New Zealand & 536.87 & 0.49 & 0.95 & 0.21 & 0.14 & 0.06 & 0.13 & 0.11 & 0.65 & 0.39 & 0.21 & 0.56 & 0.24 & 0.00 & 45.2 & 0.07 \\
\hline Sweden & 509.77 & 0.50 & 0.96 & 0.16 & 0.14 & 0.04 & 0.06 & 0.07 & 0.76 & 0.43 & 0.06 & 0.62 & 0.48 & 0.02 & 45.1 & -0.01 \\
\hline Switzerland & 529.34 & 0.50 & 0.93 & 0.13 & 0.10 & 0.08 & 0.12 & 0.19 & 0.51 & 0.14 & 0.07 & 0.48 & 0.56 & 0.03 & 45.1 & -0.02 \\
\hline UK & 529.20 & 0.50 & 0.94 & 0.20 & 0.13 & 0.06 & 0.02 & 0.04 & 0.72 & 0.33 & 0.10 & 0.49 & 0.27 & 0.08 & 45.9 & 0.09 \\
\hline USA & 493.15 & 0.51 & 0.95 & 0.20 & 0.25 & 0.07 & 0.05 & 0.11 & 0.77 & 0.30 & 0.12 & 0.46 & 0.27 & 0.23 & 46.1 & -0.17 \\
\hline
\end{tabular}

Note: the school segregation contribution (DSC) can range theoretically from -100 to +100 . A negative value refers to the percentage of natives that need to be shifted (hence overrepresentation of natives in school) and a positive value gives the percentage of immigrants that need to be shifted in the school for reaching a similar distribution of immigrants throughout all schools in the country.

\section{Table A8: TIMSS summary statistics}

\begin{tabular}{rcccccccccccccc}
\hline \hline & Math & gender & sibling & single & other & $\begin{array}{c}\text { First } \\
\text { gen }\end{array}$ & $\begin{array}{c}\text { Non } \\
\text { native }\end{array}$ & $\begin{array}{c}\text { langu } \\
\text { age }\end{array}$ & $\begin{array}{c}\text { Secon } \\
\text { educ }\end{array}$ & $\begin{array}{c}\text { Tertiary } \\
\text { educat }\end{array}$ & $\begin{array}{c}\text { Educat } \\
\text { miss }\end{array}$ & $\begin{array}{c}\text { books } \\
\text { bolisea }\end{array}$ & $\begin{array}{c}\text { Area } \\
\text { missing }\end{array}$ \\
\hline Australia & 518.87 & 0.50 & 0.89 & 0.15 & 0.10 & 0.10 & 0.10 & 0.09 & 0.47 & 0.22 & 0.20 & 0.67 & 0.15 & 0.15 \\
Canada & 520.54 & 0.50 & 0.83 & 0.18 & 0.13 & 0.11 & 0.08 & 0.10 & 0.64 & 0.35 & 0.19 & 0.58 & 0.15 & 0.15 \\
Germany & 502.31 & 0.51 & 0.76 & 0.14 & 0.09 & 0.05 & 0.08 & 0.13 & 0.27 & 0.06 & 0.30 & 0.52 & 0.12 & 0.41 \\
Netherlands & 528.84 & 0.50 & 0.90 & 0.07 & 0.06 & 0.04 & 0.03 & 0.09 & 0.50 & 0.07 & 0.34 & 0.42 & 0.00 & 1.00 \\
New Zealand & 500.94 & 0.48 & 0.88 & 0.17 & 0.13 & 0.07 & 0.08 & 0.09 & 0.52 & 0.21 & 0.29 & 0.66 & 0.15 & 0.06 \\
Sweden & 513.38 & 0.49 & 0.84 & 0.12 & 0.12 & 0.04 & 0.05 & 0.09 & 0.46 & 0.20 & 0.42 & 0.65 & 0.17 & 0.08 \\
Switzerland & 533.69 & 0.48 & 0.88 & 0.14 & 0.07 & 0.11 & 0.10 & 0.19 & 0.51 & 0.03 & 0.29 & 0.46 & 0.00 & 1.00 \\
UK & 496.02 & 0.49 & 0.88 & 0.17 & 0.14 & 0.08 & 0.03 & 0.05 & 0.04 & 0.01 & 0.95 & 0.48 & 0.12 & 0.18 \\
USA & 501.63 & 0.50 & 0.84 & 0.19 & 0.20 & 0.08 & 0.06 & 0.10 & 0.73 & 0.46 & 0.19 & 0.50 & 0.20 & 0.18 \\
\hline \hline
\end{tabular}


Table A9: PIRLS summary statistics

\begin{tabular}{|c|c|c|c|c|c|c|c|c|c|c|c|c|c|}
\hline & Read & gender & sibling & Single & $\begin{array}{l}\text { First } \\
\text { gen }\end{array}$ & $\begin{array}{l}\text { Non- } \\
\text { native }\end{array}$ & $\begin{array}{l}\text { langu } \\
\text { age }\end{array}$ & $\begin{array}{l}\text { Secon } \\
\text { educat }\end{array}$ & $\begin{array}{l}\text { Tertiar } \\
\text { educat }\end{array}$ & $\begin{array}{l}\text { Edu } \\
\text { missing }\end{array}$ & books & area & $\begin{array}{l}\text { Area } \\
\text { mis }\end{array}$ \\
\hline Canada & 544.15 & 0.50 & 0.88 & 0.10 & 0.09 & 0.14 & 0.16 & 0.70 & 0.17 & 0.23 & 0.44 & 0.20 & 0.04 \\
\hline France & 525.17 & 0.48 & 0.88 & 0.10 & 0.10 & 0.06 & 0.13 & 0.39 & 0.12 & 0.27 & 0.37 & 0.33 & 0.04 \\
\hline Germany & 539.09 & 0.50 & 0.82 & 0.08 & 0.06 & 0.08 & 0.10 & 0.49 & 0.10 & 0.39 & 0.32 & 0.42 & 0.06 \\
\hline Netherlands & 554.21 & 0.50 & 0.91 & 0.07 & 0.05 & 0.05 & 0.14 & 0.25 & 0.03 & 0.38 & 0.28 & 0.40 & 0.14 \\
\hline New Zealand & 528.82 & 0.49 & 0.90 & 0.11 & 0.08 & 0.12 & 0.16 & 0.68 & 0.21 & 0.23 & 0.45 & 0.21 & 0.05 \\
\hline Sweden & 561.01 & 0.49 & 0.91 & 0.11 & 0.06 & 0.06 & 0.10 & 0.77 & 0.25 & 0.12 & 0.57 & 0.18 & 0.03 \\
\hline UK & 550.46 & 0.52 & 0.87 & 0.13 & 0.06 & 0.08 & 0.11 & 0.23 & 0.11 & 0.51 & 0.42 & 0.20 & 0.05 \\
\hline USA & 542.15 & 0.51 & 0.86 & 0.11 & 0.07 & 0.13 & 0.15 & 0.00 & 0.00 & 1.00 & 0.42 & 0.32 & 0.04 \\
\hline
\end{tabular}

Table A10: OLS regression results for PISA maths (model 2)

\begin{tabular}{|c|c|c|c|c|c|c|c|c|c|c|}
\hline & AUS & CAN & FRA & DEU & NLD & NZL & SWE & CHE & GBR & USA \\
\hline Gender & $\begin{array}{l}-14.97 \\
(4.93) * * *\end{array}$ & $\begin{array}{l}-11.41 \\
(1.81)^{* * *}\end{array}$ & $\begin{array}{l}-17.30 \\
(3.50)^{* * *}\end{array}$ & $\begin{array}{l}-23.09 \\
(4.12)^{* * *}\end{array}$ & $\begin{array}{l}-9.08 \\
(5.20)^{*}\end{array}$ & $\begin{array}{l}-3.66 \\
(4.70)\end{array}$ & $\begin{array}{l}-12.51 \\
(3.16)^{* * *}\end{array}$ & $\begin{array}{l}-19.71 \\
(3.89)^{* * *}\end{array}$ & $\begin{array}{l}-13.60 \\
(4.63)^{* * *}\end{array}$ & $\begin{array}{l}-10.99 \\
(4.70)^{* *}\end{array}$ \\
\hline Sibling & $\begin{array}{l}-20.18 \\
(7.97)^{* *}\end{array}$ & $\begin{array}{l}-14.46 \\
(3.29)^{* * *}\end{array}$ & $\begin{array}{l}-3.23 \\
(5.45)\end{array}$ & $\begin{array}{l}2.21 \\
(4.50)\end{array}$ & $\begin{array}{l}0.56 \\
(10.46)\end{array}$ & $\begin{array}{l}-23.97 \\
(9.38) * *\end{array}$ & $\begin{array}{l}1.07 \\
(8.08)\end{array}$ & $\begin{array}{l}11.76 \\
(7.66)\end{array}$ & $\begin{array}{l}-23.60 \\
(6.35)^{* * *}\end{array}$ & $\begin{array}{l}1.73 \\
(8.01)\end{array}$ \\
\hline Single & $\begin{array}{l}-5.91 \\
(5.23)\end{array}$ & $\begin{array}{l}-14.34 \\
(2.45)^{* * *}\end{array}$ & $\begin{array}{l}-18.53 \\
(4.51)^{* * *}\end{array}$ & $\begin{array}{l}-15.08 \\
(4.96)^{* * *}\end{array}$ & $\begin{array}{l}-27.38 \\
(8.28)^{* * *}\end{array}$ & $\begin{array}{l}-18.90 \\
(5.03)^{* * *}\end{array}$ & $\begin{array}{l}-17.94 \\
(5.28)^{* * *}\end{array}$ & $\begin{array}{l}-11.34 \\
(4.75)^{* *}\end{array}$ & $\begin{array}{l}-22.90 \\
(3.66)^{* * *}\end{array}$ & $\begin{array}{l}-32.92 \\
(6.05) * * *\end{array}$ \\
\hline Other & $\begin{array}{l}-9.91 \\
(5.80)^{*}\end{array}$ & $\begin{array}{l}-22.38 \\
(2.49)^{* * *}\end{array}$ & $\begin{array}{l}-16.37 \\
(5.30)^{* * *}\end{array}$ & $\begin{array}{l}-33.07 \\
(6.39)^{* * *}\end{array}$ & $\begin{array}{l}-12.46 \\
(6.89)^{*}\end{array}$ & $\begin{array}{l}-33.45 \\
(5.18)^{* * *}\end{array}$ & $\begin{array}{l}-23.31 \\
(4.80)^{* * *}\end{array}$ & $\begin{array}{l}-27.25 \\
(6.33)^{* * *}\end{array}$ & $\begin{array}{l}-18.24 \\
(5.40)^{* * *}\end{array}$ & $\begin{array}{l}-46.19 \\
(4.81)^{* * *}\end{array}$ \\
\hline First generation & $\begin{array}{l}6.38 \\
(6.36)\end{array}$ & $\begin{array}{l}-1.44 \\
(3.76)\end{array}$ & $\begin{array}{l}-16.25 \\
(7.59)^{* *}\end{array}$ & $\begin{array}{l}-5.34 \\
(9.32)\end{array}$ & $\begin{array}{l}-46.88 \\
(14.65)^{* *} \\
*\end{array}$ & $\begin{array}{l}-7.50 \\
(10.68)\end{array}$ & $\begin{array}{l}-27.97 \\
(11.04) * *\end{array}$ & $\begin{array}{l}-25.78 \\
(8.42)^{* * *}\end{array}$ & $\begin{array}{l}-7.17 \\
(9.17)\end{array}$ & $\begin{array}{l}14.22 \\
(11.84)\end{array}$ \\
\hline Non-native & $\begin{array}{l}0.02 \\
(7.28)\end{array}$ & $\begin{array}{l}-8.10 \\
(5.23)\end{array}$ & $\begin{array}{l}-45.69 \\
(15.06)^{* *} \\
*\end{array}$ & $\begin{array}{l}-23.47 \\
(11.72) * *\end{array}$ & $\begin{array}{l}-78.24 \\
(17.17)^{* *} \\
*\end{array}$ & $\begin{array}{l}17.52 \\
(7.52)^{* *}\end{array}$ & $\begin{array}{l}-28.60 \\
(12.80)^{* *}\end{array}$ & $\begin{array}{l}-47.88 \\
(7.30)^{* * *}\end{array}$ & $\begin{array}{l}-4.28 \\
(20.48)\end{array}$ & $\begin{array}{l}22.87 \\
(12.85)^{*}\end{array}$ \\
\hline Language & $\begin{array}{l}-13.64 \\
(6.92)^{*}\end{array}$ & $\begin{array}{l}-4.83 \\
(3.59)\end{array}$ & $\begin{array}{l}-26.14 \\
(8.18)^{* * *}\end{array}$ & $\begin{array}{l}-56.42 \\
(11.89) * * \\
*\end{array}$ & $\begin{array}{l}-14.88 \\
(8.08)^{*}\end{array}$ & $\begin{array}{l}-42.65 \\
(9.44) * * *\end{array}$ & $\begin{array}{l}-30.53 \\
(12.68) * *\end{array}$ & $\begin{array}{l}-32.27 \\
(6.28)^{* * *}\end{array}$ & $\begin{array}{l}-36.29 \\
(9.21)^{* * *}\end{array}$ & $\begin{array}{l}-56.95 \\
(15.34)^{* *} \\
*\end{array}$ \\
\hline $\begin{array}{l}\text { Mother } \\
\text { secondary }\end{array}$ & $\begin{array}{l}14.27 \\
(5.30)^{* * *}\end{array}$ & $\begin{array}{l}18.88 \\
(2.78) * * *\end{array}$ & $\begin{array}{l}26.64 \\
(4.13)^{* * *}\end{array}$ & $\begin{array}{l}32.64 \\
(5.22)^{* * *}\end{array}$ & $\begin{array}{l}12.50 \\
(5.76)^{* *}\end{array}$ & $\begin{array}{l}20.05 \\
(5.61)^{* * *}\end{array}$ & $\begin{array}{l}19.95 \\
(5.46)^{* * *}\end{array}$ & $\begin{array}{l}38.20 \\
(4.39)^{* * *}\end{array}$ & $\begin{array}{l}18.23 \\
(4.47)^{* * *}\end{array}$ & $\begin{array}{l}35.61 \\
(7.75)^{* * *}\end{array}$ \\
\hline Mother tertiary & $\begin{array}{l}29.64 \\
(4.92)^{* * *}\end{array}$ & $\begin{array}{l}18.05 \\
(2.22)^{* * *}\end{array}$ & $\begin{array}{l}1.83 \\
(4.32) \\
\end{array}$ & $\begin{array}{l}35.69 \\
(5.90)^{* * *}\end{array}$ & $\begin{array}{l}5.32 \\
(7.70)\end{array}$ & $\begin{array}{l}20.21 \\
(4.15)^{* * *}\end{array}$ & $\begin{array}{l}-0.10 \\
(3.67)\end{array}$ & $\begin{array}{l}-1.46 \\
(4.91)\end{array}$ & $\begin{array}{l}12.41 \\
(4.24)^{* * *}\end{array}$ & $\begin{array}{l}23.96 \\
(5.32)^{* * *}\end{array}$ \\
\hline Education mis & $\begin{array}{l}-23.61 \\
(8.73) * * *\end{array}$ & $\begin{array}{l}-30.75 \\
(7.59) * * *\end{array}$ & $\begin{array}{l}-39.91 \\
(8.07)^{* * *}\end{array}$ & $\begin{array}{l}9.18 \\
(8.45)\end{array}$ & $\begin{array}{l}-56.38 \\
(11.49) * * \\
*\end{array}$ & $\begin{array}{l}-17.36 \\
(6.33)^{* * *}\end{array}$ & $\begin{array}{l}-35.03 \\
(9.50)^{* * *}\end{array}$ & $\begin{array}{l}-28.89 \\
(7.95)^{* * *}\end{array}$ & $\begin{array}{l}-26.02 \\
(7.19)^{* * *}\end{array}$ & $\begin{array}{l}-12.34 \\
(9.80)\end{array}$ \\
\hline Books at home & $\begin{array}{l}34.14 \\
(4.19) * * *\end{array}$ & $\begin{array}{l}26.10 \\
(1.96)^{* * *}\end{array}$ & $\begin{array}{l}34.43 \\
(3.84)^{* * *}\end{array}$ & $\begin{array}{l}50.58 \\
(4.45) * * *\end{array}$ & $\begin{array}{l}41.25 \\
(6.20)^{* * *}\end{array}$ & $\begin{array}{l}44.59 \\
(4.51)^{* * *}\end{array}$ & $\begin{array}{l}36.68 \\
(4.09) * * *\end{array}$ & $\begin{array}{l}41.85 \\
(3.98)^{* * *}\end{array}$ & $\begin{array}{l}46.16 \\
(4.24)^{* * *}\end{array}$ & $\begin{array}{l}44.55 \\
(4.58) * * *\end{array}$ \\
\hline Area & $\begin{array}{l}-18.72 \\
(5.97)^{* * *}\end{array}$ & & $\begin{array}{l}-32.27 \\
(8.60) * * *\end{array}$ & $\begin{array}{l}-13.70 \\
(7.98)^{*}\end{array}$ & $\begin{array}{l}4.07 \\
(16.13)\end{array}$ & $\begin{array}{l}-11.11 \\
(6.19)^{*}\end{array}$ & $\begin{array}{l}-8.65 \\
(4.22)^{* *}\end{array}$ & $\begin{array}{l}-15.29 \\
(7.84)^{*}\end{array}$ & $\begin{array}{l}1.09 \\
(5.51)\end{array}$ & $\begin{array}{l}-18.94 \\
(7.59)^{* *}\end{array}$ \\
\hline Area missing & & & $\begin{array}{l}3.99 \\
(10.30)\end{array}$ & $\begin{array}{l}-15.39 \\
(12.21)\end{array}$ & $\begin{array}{l}24.89 \\
(21.50)\end{array}$ & & $\begin{array}{l}6.90 \\
(15.45)\end{array}$ & $\begin{array}{l}0.72 \\
(24.32)\end{array}$ & $\begin{array}{l}-4.72 \\
(8.71)\end{array}$ & $\begin{array}{l}7.83 \\
(10.71)\end{array}$ \\
\hline Constant & $\begin{array}{l}529.42 \\
(9.30) * * *\end{array}$ & $\begin{array}{l}522.81 \\
(4.28)^{* * *}\end{array}$ & $\begin{array}{l}520.41 \\
(7.91)^{* * *}\end{array}$ & $\begin{array}{l}475.82 \\
(8.29) * * *\end{array}$ & $\begin{array}{l}560.54 \\
(12.29)^{* *} \\
*\end{array}$ & $\begin{array}{l}538.76 \\
(11.79)^{* *} \\
*\end{array}$ & $\begin{array}{l}496.65 \\
(9.28)^{* * *}\end{array}$ & $\begin{array}{l}518.89 \\
(10.75)^{* *} \\
*\end{array}$ & $\begin{array}{l}533.11 \\
(7.74)^{* * *}\end{array}$ & $\begin{array}{l}471.43 \\
(10.79)^{* *} \\
*\end{array}$ \\
\hline Observations & 2768 & 15712 & 2356 & 2442 & 1314 & 1873 & 2362 & 3173 & 4927 & 1878 \\
\hline R-squared & 0.13 & 0.10 & 0.21 & 0.26 & 0.25 & 0.19 & 0.14 & 0.29 & 0.17 & 0.28 \\
\hline
\end{tabular}


Table A11: OLS regression results for TIMSS maths (model 2)

\begin{tabular}{|c|c|c|c|c|c|c|c|c|c|}
\hline & AUS & CAN & DEU & NLD & NZL & SWE & CHE & GBR & USA \\
\hline First generation & $\begin{array}{l}-2.44 \\
(5.50) \\
\end{array}$ & $\begin{array}{l}-5.85 \\
(4.95) \\
\end{array}$ & $\begin{array}{l}5.75 \\
(10.70)\end{array}$ & $\begin{array}{l}-8.20 \\
(11.78)\end{array}$ & $\begin{array}{l}-21.01 \\
(6.52) * * *\end{array}$ & $\begin{array}{l}-7.09 \\
(6.35) \\
\end{array}$ & $\begin{array}{l}-19.10 \\
(6.85)^{* * *}\end{array}$ & $\begin{array}{l}13.46 \\
(7.01)^{*}\end{array}$ & $\begin{array}{l}-1.41 \\
(5.77) \\
\end{array}$ \\
\hline Non-native & $\begin{array}{l}15.55 \\
(5.67)^{* * *}\end{array}$ & $\begin{array}{l}-5.63 \\
(7.81)\end{array}$ & $\begin{array}{l}-10.15 \\
(8.37)\end{array}$ & $\begin{array}{l}-38.76 \\
(17.33) * *\end{array}$ & $\begin{array}{l}22.87 \\
(7.78) * * *\end{array}$ & $\begin{array}{l}-27.83 \\
(7.05)^{* * *}\end{array}$ & $\begin{array}{l}-25.61 \\
(7.75)^{* * *}\end{array}$ & $\begin{array}{l}18.60 \\
(10.58)^{*}\end{array}$ & $\begin{array}{l}-11.26 \\
(7.22)\end{array}$ \\
\hline Language & $\begin{array}{l}-29.03 \\
(6.10)^{* * *}\end{array}$ & $\begin{array}{l}-15.05 \\
(5.86)^{* *}\end{array}$ & $\begin{array}{l}-38.54 \\
(7.81)^{* * *}\end{array}$ & $\begin{array}{l}8.59 \\
(7.66)\end{array}$ & $\begin{array}{l}24.43 \\
(6.66)^{* * *}\end{array}$ & $\begin{array}{l}-11.20 \\
(7.58)\end{array}$ & $\begin{array}{l}-33.82 \\
(5.81)^{* * *}\end{array}$ & $\begin{array}{l}-26.22 \\
(8.48)^{* * * *}\end{array}$ & $\begin{array}{l}-30.19 \\
(3.99)^{* * *}\end{array}$ \\
\hline Gender & $\begin{array}{l}0.42 \\
(3.63)\end{array}$ & $\begin{array}{l}1.45 \\
(3.05)\end{array}$ & $\begin{array}{l}-7.57 \\
(3.92)^{*}\end{array}$ & $\begin{array}{l}-13.32 \\
(4.02)^{* * *}\end{array}$ & $\begin{array}{l}-8.34 \\
(5.23)\end{array}$ & $\begin{array}{l}-6.37 \\
(2.91)^{* *}\end{array}$ & $\begin{array}{l}-8.28 \\
(2.71)^{* * *}\end{array}$ & $\begin{array}{l}-17.87 \\
(5.57)^{* * *}\end{array}$ & $\begin{array}{l}-11.00 \\
(2.11)^{* * * *}\end{array}$ \\
\hline Sibling & $\begin{array}{l}3.01 \\
(3.96)\end{array}$ & $\begin{array}{l}1.50 \\
(4.68)\end{array}$ & $\begin{array}{l}1.28 \\
(3.55)\end{array}$ & $\begin{array}{l}-6.35 \\
(8.83)\end{array}$ & $\begin{array}{l}7.57 \\
(3.45) * *\end{array}$ & $\begin{array}{l}7.77 \\
(3.35) * *\end{array}$ & $\begin{array}{l}8.16 \\
(3.44) * *\end{array}$ & $\begin{array}{l}-3.86 \\
(4.72)\end{array}$ & $\begin{array}{l}0.56 \\
(2.52)\end{array}$ \\
\hline Single & $\begin{array}{l}-7.64 \\
(2.98)^{* *}\end{array}$ & $\begin{array}{l}-19.54 \\
(3.40)^{* * *}\end{array}$ & $\begin{array}{l}-11.65 \\
(5.42) * *\end{array}$ & $\begin{array}{l}-4.72 \\
(6.51)\end{array}$ & $\begin{array}{l}17.28 \\
(3.70)^{* * *}\end{array}$ & $\begin{array}{l}-3.23 \\
(3.96)\end{array}$ & $\begin{array}{l}-10.75 \\
(3.76)^{* * *}\end{array}$ & $\begin{array}{l}-16.30 \\
(3.56)^{* * *}\end{array}$ & $\begin{array}{l}24.93 \\
(3.02)^{* * *}\end{array}$ \\
\hline Other & $\begin{array}{l}-23.43 \\
(3.66) * * *\end{array}$ & $\begin{array}{l}-10.95 \\
(3.67)^{* * *}\end{array}$ & $\begin{array}{l}-21.53 \\
(5.08) * * *\end{array}$ & $\begin{array}{l}-47.64 \\
(15.83)^{* *} \\
*\end{array}$ & $\begin{array}{l}-31.12 \\
(4.35) * * *\end{array}$ & $\begin{array}{l}-16.71 \\
(3.63) * * *\end{array}$ & $\begin{array}{l}-9.16 \\
(5.12)^{*}\end{array}$ & $\begin{array}{l}-28.19 \\
(4.26) * * *\end{array}$ & $\begin{array}{l}-31.06 \\
(3.34)^{* * * *}\end{array}$ \\
\hline Mother secondary & $\begin{array}{l}5.89 \\
(3.06)^{*}\end{array}$ & $\begin{array}{l}13.53 \\
(3.24)^{* * *}\end{array}$ & $\begin{array}{l}11.04 \\
(4.27)^{* *}\end{array}$ & $\begin{array}{l}16.28 \\
(5.72)^{* * *}\end{array}$ & $\begin{array}{l}3.75 \\
(4.31)\end{array}$ & $\begin{array}{l}20.91 \\
(3.66) * * *\end{array}$ & $\begin{array}{l}12.15 \\
(3.99)^{* * *}\end{array}$ & $\begin{array}{l}5.50 \\
(4.46)\end{array}$ & $\begin{array}{l}19.13 \\
(3.84) * * *\end{array}$ \\
\hline Mother tertiary & $\begin{array}{l}26.90 \\
(3.32)^{* * *}\end{array}$ & $\begin{array}{l}10.85 \\
(3.20)^{* * *}\end{array}$ & $\begin{array}{l}18.96 \\
(8.08)^{* *}\end{array}$ & $\begin{array}{l}-4.48 \\
(12.60)\end{array}$ & $\begin{array}{l}27.25 \\
(4.48)^{* * *}\end{array}$ & $\begin{array}{l}6.68 \\
(2.89) * *\end{array}$ & $\begin{array}{l}30.43 \\
(8.30)^{* * *}\end{array}$ & $\begin{array}{l}30.33 \\
(9.32)^{* * *}\end{array}$ & $\begin{array}{l}21.79 \\
(3.18) * * *\end{array}$ \\
\hline Education mis & $\begin{array}{l}-21.67 \\
(3.70)^{* * *}\end{array}$ & $\begin{array}{l}-3.59 \\
(4.53)\end{array}$ & $\begin{array}{l}-17.16 \\
(4.40)^{* * *}\end{array}$ & $\begin{array}{l}-2.64 \\
(6.27)\end{array}$ & $\begin{array}{l}-9.59 \\
(3.86)^{* *}\end{array}$ & $\begin{array}{l}6.31 \\
(3.78) *\end{array}$ & $\begin{array}{l}-7.44 \\
(3.78)^{*}\end{array}$ & $\begin{array}{l}-0.38 \\
(4.92)\end{array}$ & $\begin{array}{l}1.69 \\
(3.96)\end{array}$ \\
\hline Books at home & $\begin{array}{l}38.12 \\
(3.00)^{* * *}\end{array}$ & $\begin{array}{l}6.97 \\
(2.50) * * *\end{array}$ & $\begin{array}{l}48.29 \\
(4.25)^{* * *}\end{array}$ & $\begin{array}{l}37.20 \\
(6.49)^{* * *}\end{array}$ & $\begin{array}{l}39.06 \\
(3.64) * * *\end{array}$ & $\begin{array}{l}34.11 \\
(3.30)^{* * * *}\end{array}$ & $\begin{array}{l}31.42 \\
(3.15)^{* * *}\end{array}$ & $\begin{array}{l}46.18 \\
(4.70)^{* * * *}\end{array}$ & $\begin{array}{l}36.82 \\
(2.35) * * *\end{array}$ \\
\hline Area & $\begin{array}{l}-13.52 \\
(11.30)\end{array}$ & $\begin{array}{l}8.91 \\
(7.73) \\
\end{array}$ & $\begin{array}{l}-12.40 \\
(12.62)\end{array}$ & & $\begin{array}{l}-7.64 \\
(8.97)\end{array}$ & $\begin{array}{l}-11.05 \\
(6.45)^{*}\end{array}$ & & $\begin{array}{l}20.24 \\
(11.08)^{*}\end{array}$ & $\begin{array}{l}-10.88 \\
(5.90)^{*}\end{array}$ \\
\hline Area missing & $\begin{array}{l}10.65 \\
(9.54)\end{array}$ & $\begin{array}{l}9.96 \\
(14.55)\end{array}$ & $\begin{array}{l}-14.15 \\
(8.87)\end{array}$ & & $\begin{array}{l}-21.39 \\
(12.68)^{*}\end{array}$ & $\begin{array}{l}-18.66 \\
(6.86)^{* * *}\end{array}$ & & $\begin{array}{l}-10.39 \\
(9.75)\end{array}$ & $\begin{array}{l}-0.77 \\
(8.11)\end{array}$ \\
\hline Constant & $\begin{array}{l}494.34 \\
(6.81)^{* * *}\end{array}$ & $\begin{array}{l}509.19 \\
(7.11)^{* * *}\end{array}$ & $\begin{array}{l}499.12 \\
(7.32)^{* * *}\end{array}$ & $\begin{array}{l}524.26 \\
(8.94) * * *\end{array}$ & $\begin{array}{l}480.24 \\
(6.91)^{* * *}\end{array}$ & $\begin{array}{l}486.80 \\
(5.88)^{* * *}\end{array}$ & $\begin{array}{l}526.08 \\
(5.88) * * *\end{array}$ & $\begin{array}{l}494.53 \\
(7.17)^{* * *}\end{array}$ & $\begin{array}{l}485.39 \\
(6.04)^{* * * *}\end{array}$ \\
\hline Observations & 6532 & 7883 & 2321 & 1769 & 3523 & 3260 & 4645 & 5222 & 8115 \\
\hline R-squared & 0.15 & 0.06 & 0.23 & 0.13 & 0.17 & 0.15 & 0.26 & 0.15 & 0.20 \\
\hline
\end{tabular}


Table A12: OLS regression results for PIRLS reading (model 2)

\begin{tabular}{|c|c|c|c|c|c|c|c|c|}
\hline & CAN & FRA & DEU & NLD & NZL & SWE & GBR & USA \\
\hline Gender & $\begin{array}{l}14.1 \\
(1.4)^{* * *}\end{array}$ & $\begin{array}{l}9.6 \\
(2.0) * * *\end{array}$ & $\begin{array}{l}9.8 \\
(1.3) * * *\end{array}$ & $\begin{array}{l}13.2 \\
(1.5)^{* * *}\end{array}$ & $\begin{array}{l}25.3 \\
(3.3) * * *\end{array}$ & $\begin{array}{l}20.5 \\
(1.5)^{* * * *}\end{array}$ & $\begin{array}{l}17.9 \\
(2.6) * * *\end{array}$ & $\begin{array}{l}14.6 \\
(2.4) * * *\end{array}$ \\
\hline Sibling & $\begin{array}{l}-3.2 \\
(2.2)\end{array}$ & $\begin{array}{l}-4.4 \\
(3.1)\end{array}$ & $\begin{array}{l}-4.5 \\
(1.6) * * *\end{array}$ & $\begin{array}{l}3.3 \\
(2.7)\end{array}$ & $\begin{array}{l}-1.4 \\
(5.4)\end{array}$ & $\begin{array}{l}0.3 \\
(2.6) \\
\end{array}$ & $\begin{array}{l}-6.6 \\
(4.0) \\
\end{array}$ & $\begin{array}{l}-6.9 \\
(3.4)^{* *}\end{array}$ \\
\hline Single & $\begin{array}{l}-11.2 \\
(2.5) * * *\end{array}$ & $\begin{array}{l}-3.8 \\
(3.2)\end{array}$ & $\begin{array}{l}-3.3 \\
(2.3)\end{array}$ & $\begin{array}{l}-2.7 \\
(2.8)\end{array}$ & $\begin{array}{l}1.1 \\
(5.2)\end{array}$ & $\begin{array}{l}0.4 \\
(2.6)\end{array}$ & $\begin{array}{l}-4.8 \\
(4.1)\end{array}$ & $\begin{array}{l}-12.9 \\
(4.2)^{* * *}\end{array}$ \\
\hline First generation & $\begin{array}{l}10.9 \\
(2.6)^{* * *}\end{array}$ & $\begin{array}{l}-6.6 \\
(3.7)^{*}\end{array}$ & $\begin{array}{l}-13.2 \\
(3.3)^{* * * *}\end{array}$ & $\begin{array}{l}-35.0 \\
(3.5)^{* * *}\end{array}$ & $\begin{array}{l}16.5 \\
(6.3)^{* * * *}\end{array}$ & $\begin{array}{l}-8.1 \\
(3.5)^{* *}\end{array}$ & $\begin{array}{l}14.9 \\
(5.5)^{* * *}\end{array}$ & $\begin{array}{l}4.1 \\
(4.3)\end{array}$ \\
\hline Non-native & $\begin{array}{l}-17.5 \\
(2.3)^{* * * *}\end{array}$ & $\begin{array}{l}-17.7 \\
(4.3) * * *\end{array}$ & $\begin{array}{l}-31.9 \\
(2.7)^{* * *}\end{array}$ & $\begin{array}{l}-22.4 \\
(3.7) * * *\end{array}$ & $\begin{array}{l}7.7 \\
(5.2)\end{array}$ & $\begin{array}{l}-29.0 \\
(3.9) * * *\end{array}$ & $\begin{array}{l}-31.9 \\
(4.9) * * *\end{array}$ & $\begin{array}{l}-36.2 \\
(4.0) * * *\end{array}$ \\
\hline Language & $\begin{array}{l}-38.9 \\
(1.7)^{* * *}\end{array}$ & $\begin{array}{l}-25.3 \\
(3.3)^{* * *}\end{array}$ & $\begin{array}{l}-31.1 \\
(2.7)^{* * *}\end{array}$ & $\begin{array}{l}-13.6 \\
(2.3)^{* * * *}\end{array}$ & $\begin{array}{l}-50.1 \\
(5.1)^{* * * *}\end{array}$ & $\begin{array}{l}-22.5 \\
(3.1)^{* * *}\end{array}$ & $\begin{array}{l}-40.3 \\
(4.3) * * *\end{array}$ & $\begin{array}{l}-45.3 \\
(3.8)^{* * * *}\end{array}$ \\
\hline Mother secondary & $\begin{array}{l}19.1 \\
(2.9)^{* * *}\end{array}$ & $\begin{array}{l}28.9 \\
(2.6) * * *\end{array}$ & $\begin{array}{l}33.6 \\
(2.3)^{* * *}\end{array}$ & $\begin{array}{l}26.7 \\
(2.0)^{* * *} *\end{array}$ & $\begin{array}{l}31.1 \\
(6.3) * * *\end{array}$ & $\begin{array}{l}22.1 \\
(2.7)^{* * * *}\end{array}$ & $\begin{array}{l}21.8 \\
(4.6) * * *\end{array}$ & \\
\hline Mother tertiary & $\begin{array}{l}27.8 \\
(1.9) * * *\end{array}$ & $\begin{array}{l}27.4 \\
(3.2) * * *\end{array}$ & $\begin{array}{l}20.9 \\
(2.1)^{* * *}\end{array}$ & $\begin{array}{l}12.2 \\
(4.7)^{* *}\end{array}$ & $\begin{array}{l}32.8 \\
(3.9) * * *\end{array}$ & $\begin{array}{l}22.5 \\
(1.7) * * *\end{array}$ & $\begin{array}{l}25.6 \\
(5.2) * * *\end{array}$ & \\
\hline Education mis & $\begin{array}{l}3.3 \\
(3.1)\end{array}$ & $\begin{array}{l}1.5 \\
(2.8)\end{array}$ & $\begin{array}{l}15.3 \\
(2.4) * * *\end{array}$ & $\begin{array}{l}-6.0 \\
(1.8) * * *\end{array}$ & $\begin{array}{l}1.1 \\
(7.1)\end{array}$ & $\begin{array}{l}8.0 \\
(3.3)^{* *}\end{array}$ & $\begin{array}{l}-16.1 \\
(3.2) * * *\end{array}$ & \\
\hline Books at home & $\begin{array}{l}18.6 \\
(1.5)^{* * *}\end{array}$ & $\begin{array}{l}22.1 \\
(2.2) * * *\end{array}$ & $\begin{array}{l}26.2 \\
(1.5)^{* * * *}\end{array}$ & $\begin{array}{l}11.9 \\
(1.7)^{* * *}\end{array}$ & $\begin{array}{l}31.4 \\
(3.3) * * *\end{array}$ & $\begin{array}{l}18.1 \\
(1.6) * * *\end{array}$ & $\begin{array}{l}30.7 \\
(2.7)^{* * * *}\end{array}$ & $\begin{array}{l}33.6 \\
(2.5)^{* * *}\end{array}$ \\
\hline Area & $\begin{array}{l}-9.5 \\
(2.0)^{* * *}\end{array}$ & $\begin{array}{l}2.2 \\
(2.4)\end{array}$ & $\begin{array}{l}8.9 \\
(1.4) * * *\end{array}$ & $\begin{array}{l}4.9 \\
(1.7) * * *\end{array}$ & $\begin{array}{l}8.6 \\
(4.3) * *\end{array}$ & $\begin{array}{l}-4.3 \\
(2.3)^{*}\end{array}$ & $\begin{array}{l}15.3 \\
(3.1) * * *\end{array}$ & $\begin{array}{l}-14.1 \\
(3.0)^{* * *}\end{array}$ \\
\hline Area missing & $\begin{array}{l}8.3 \\
(2.8) * * *\end{array}$ & $\begin{array}{l}2.7 \\
(5.3)\end{array}$ & $\begin{array}{l}15.5 \\
(2.8) * * *\end{array}$ & $\begin{array}{l}3.7 \\
(2.5)\end{array}$ & $\begin{array}{l}9.5 \\
(7.4)\end{array}$ & $\begin{array}{l}-8.1 \\
(5.1)\end{array}$ & $\begin{array}{l}-6.1 \\
(6.8)\end{array}$ & $\begin{array}{l}-38.7 \\
(7.0)^{* * *}\end{array}$ \\
\hline Constant & $\begin{array}{l}520.4 \\
(3.5)^{* * *}\end{array}$ & $\begin{array}{l}509.8 \\
(3.5)^{* * *}\end{array}$ & $\begin{array}{l}509.1 \\
(2.7)^{* * * *}\end{array}$ & $\begin{array}{l}542.9 \\
(3.1)^{* * *}\end{array}$ & $\begin{array}{l}485.4 \\
(8.4)^{* * * *}\end{array}$ & $\begin{array}{l}525.2 \\
(3.5)^{* * * *}\end{array}$ & $\begin{array}{l}543.4 \\
(4.9)^{* * *}\end{array}$ & $\begin{array}{l}550.7 \\
(3.8)^{* * *}\end{array}$ \\
\hline Observations & 7431 & 3211 & 6607 & 3818 & 2283 & 5701 & 3047 & 3575 \\
\hline R-squared & 0.18 & 0.21 & 0.24 & 0.19 & 0.20 & 0.19 & 0.21 & 0.17 \\
\hline
\end{tabular}

